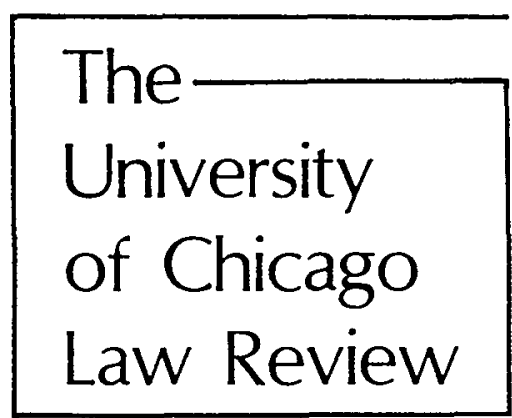

VOLUME 57 NUMBER 1 WINTER 1990

1990 by The University of Chicago

\title{
The Risk of Legal Error in Criminal Cases: Some Consequences of the Asymmetry in the Right to Appeal
}

\author{
Kate Stith $\dagger$ \\ Table of Contents
}

Introduction $\ldots \ldots \ldots \ldots \ldots \ldots \ldots \ldots \ldots \ldots \ldots \ldots$

I. The Asymmetric Risk of Legal Error in Criminal Cases .............................. 8

A. The Essential Structure of Legal Error ....... 9

B. The Essential Structure of Criminal Trial and Appeal .......................... 12

C. The Incidence of Legal Error ............. 15

1. The distribution of disputes and error at

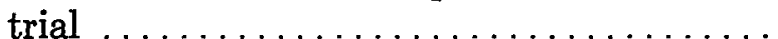

2. The distribution of disputes and error on appeal $\ldots \ldots \ldots \ldots \ldots \ldots \ldots \ldots \ldots \ldots, 16$

II. Selection Effects in Criminal Appeals .......... 18

† Associate Professor of Law, Yale Law School. A.B. Dartmouth College; J.D. Harvard Law School; M.P.P. Harvard University. I appreciate the lively discussion upon presenting an earlier version of this article to the Columbia Law School Legal Theory Workshop, and the advice and critical observations, at various stages of the endeavor, of my colleagues Bruce Ackerman, Akhil Amar, Lea Brilmayer, Mirjan Damaska, Robert Ellickson, Henry Hansmann, Alvin Klevorick, Jerry Mashaw, George Priest, and Roberta Romano. I am also grateful to J. Hoult Verkerke, Yale Law School Class of 1990, who provided helpful comments and wrote the computer program to generate the graphs in the Appendix, and to Giberto Marxauch, Yale Law School Class of 1991, who greatly assisted in gathering data. 
A. Selection Effects in the Trial Court ........ 19

1. Inferring the legal standard from precedent 19

2. Sampling precedent $\ldots \ldots \ldots \ldots \ldots \ldots \ldots, 20$

3. Balancing instead of minimizing inconsistency in appellate precedent ......... 22

B. Selection Effects in the Appellate Court ..... 25

1. Pro-defendant bias ................. 25

2. Pro-government bias ............... 27

III. Counteracting Selection Effects............ 28

A. Altering the Distribution of Disputes ....... 29

1. The distribution of disputes without selection effects ................. 29

2. Strategic response to selection effects .... 31

B. Self-Correction of Selection Effects ......... 33

C. Irrelevant Appellate Argument and Appellate Dicta ............................. 33

D. Exogenous Correction of Selection Effects.... 36

IV. Incentives for Trial Court Error ............... 36

A. Reducing the Risk of Reversal .......... 37

B. To Avoid Reversal or to Avoid Uncorrected Error? ............................. 38

V. The Consequences of "Harmless Error" ......... 43

A. The Meaning of Harmless Error ......... 43

B. The Risk of Error with a Harmless Error Rule 44

C. Harmless Error and the Legal Standard Applied in the Trial Court .................... 46

1. Assuming that trial courts seek only to apply the authoritative legal standard.... 46

2. Assuming that trial courts also seek to avoid error in final judgments and to avoid reversal ........................ 46

D. Harmless Error and the Appellate Court..... 48

Conclusion ........................... $\quad 50$

Appendix: Graphic Analysis of the Risk of Error ....... 56 


\section{INTRODUCTION}

The government bears most of the risk of error in a criminal trial: factual error because of the requirement of proof beyond a reasonable doubt ${ }^{1}$ and legal error because of the prohibition on government appeal of acquittals. ${ }^{2}$ Neither of these procedural mechanisms has a counterpart in civil procedure.

An important consequence of the asymmetric risk of error in criminal cases is that there are more acquittals than there would be under symmetric risk of error, ceteris paribus. That is, assuming all other rules of criminal procedure and evidence remain the same, more defendants would be convicted (by guilty plea or after trial) under the civil standard of preponderance of the evidence than are convicted under the reasonable doubt standard. Similarly, if appeal by the government were allowed, some acquitted defendants would suffer reversal and be convicted at a retrial.

Other commentators have analyzed the effect of the criminal system's higher standard of proof on the risk of factual error at trial. ${ }^{3}$ These analyses show that raising the burden of proof increases the likelihood of false negatives (acquittals of "factually guilty" persons), and decreases the likelihood of false positives (convictions of "factually innocent" persons). The civil preponderance of the evidence standard minimizes the risk - the expected total-of factual errors. ${ }^{4}$ The criminal system's higher burden of

1 The Due Process Clause requires this burden of proof. In Re Winship, 397 US 358, 364 (1970).

2 The Constitution's prohibition on double jeopardy requires this rule. US Const, Amend V; Kepner $v$ United States, 195 US 100, 126 (1904); and Benton v Maryland, 395 US 784, 795-97 (1969). See also United States v Ball, 163 US 662, 671 (1896) (dictum).

3 See, for example, V. C. Ball, The Moment of Truth: Probability Theory and Standards of Proof, 14 Vand L Rev 807, 815-16 (1961); and Stephen E. Fienberg \& Joseph B. Kadane, The Presentation of Bayesian Statistical Analyses in Legal Proceedings, 32 The Statistician 88 (1983). See generally David Kaye, The Laws of Probability and the Law of the Land, $47 \mathrm{U}$ Chi L Rev 34 (1979).

- Under a preponderance standard, the plaintiff must show that his allegations are "more likely than not" true. This standard minimizes the expected total of false negatives and false positives. See Ball, 14 Vand $L$ Rev at 817 (cited in note 3); and David Kaye, Naked Statistical Evidence, 89 Yale L J 601, 603-05 (1980) (book review of Michael O. Finkelstein, Quantitative Methods in Law (Free Press, 1978)). Only this standard treats the cost of factual error against the defendant and the cost of factual error against the plaintiff as equal (except at the point of equipoise, where the defendant prevails). See Kaye, 89 Yale $\mathrm{L} J$ at 608 (cited in note 3); and Lea Brilmayer and Lewis Kornhauser, Review: Quantitative Methods and Legal Decisions, 46 U Chi L Rev 116, 151 (1978) (also reviewing Finkelstein's Quantitative Methods in Law).

A few commentators have suggested that the burden of proof should be set so as to equalize the probability of pro-plaintiff factual error and pro-defendant factual error. See, for example, Finkelstein, Quantitative Methods in Law at 59-104; and Laurence H. Tribe, 
proof on the government increases the risk of factual error, in the pro-defendant direction. The imposition of a higher burden of proof in criminal cases indicates, of course, that minimizing the risk of factual error is not the only goal of the criminal process. In the Anglo-American tradition, the social cost of factual error against the defendant (a "false positive") is deemed greater than the social cost of factual error against the government (a "false negative"). ${ }^{5}$

In this article I examine some consequences of asymmetric risk of legal error ${ }^{6}$ in criminal cases. While the burden of proof is the major procedural mechanism for apportioning the risk of factual error, the body of rules governing appellate review is the major procedural mechanism for apportioning the risk of legal error. ${ }^{7}$ The most basic of these rules is that a defendant can appeal a conviction by alleging pro-government legal error in the trial court,

Trial By Mathematics: Precision and Ritual in the Legal Process, 84 Harv L Rev 1329, 1349-50 (1971). But unless the distribution of disputes concerning the relevant issue is symmetric with respect to the legal standard, this goal implies a bias for the defendant or the plaintiff in particular cases. See illustration in Kaye, 89 Yale L J at 604-07. See also James Brook, Inevitable Errors: The Preponderance of the Evidence Standard in Civil Litigation, 18 Tulsa L J 79, 107-08 (1982) and note 63, below.

s See also Barbara D. Underwood, The Thumb on the Scales of Justice: Burdens of Persuasion in Criminal Cases, 86 Yale L J 1299, 1302 n 9 (1977) (the reasonable doubt formulation, which has been used for two centuries in Anglo-American law, was intended to guard against use of an even higher standard of proof).

- There is some confusion in the literature between factual error, legal error, and "outcome" error. Some scholars refer to errors in trial outcomes-acquittals of guilty defendants or convictions of innocent defendants-as factual errors. See, for example, sources cited in notes 3 and 4. Occasionally, however, scholars refer to incorrect outcomes as legal errors. See, for example, A. Mitchell Polinsky and Steven Shavell, Legal Error, Litigation, and the Incentive to Obey the Law, $5 \mathrm{~J}$ L Econ \& Org 99-100 (1989). The use of general jury verdicts rather than special verdicts in criminal cases makes it difficult to determine whether an error in the final outcome stems from errors in ascertaining the underlying facts or from wrongly applying a legal standard to the underlying facts. See also note 25 . Legal error in the latter sense may or may not result in an error in trial outcome. See note 8 . Moreover, outcome errors are also related to the burden of proof, the peculiarities of jury decision making, evidentiary rules, and other factors.

' In addition to direct appeal, state and federal collateral review is available to a defendant, for instance on a petition for a writ of habeas corpus. Collateral review operates similarly to direct appeal, in effect permitting additional stages of appellate review of criminal cases. See James Liebman, Federal Habeas Corpus Practice and Procedure 386-88 (Michie, 1988) (in the last quarter century, the legal system has explicitly come to accept federal habeas corpus as a continuation of the appellate process, preceding finality rather than operating as a truly collateral remedy); and Paul D. Carrington, Daniel J. Meador, and Maurice Rosenberg, Justice on Appeal 103-05 (West, 1976). For the present analysis, I ignore the consequences of collateral review in criminal cases, except to note here that habeas corpus review creates further asymmetry between pro-government and pro-defendant legal error. 
but the government cannot appeal an acquittal by alleging pro-defendant error.

To some extent, analysis of the risk of legal error parallels that of factual error. Legal error at trial may result in the acquittal of a defendant who would otherwise have been convicted (a false negative), or it may result in the conviction of a defendant who would otherwise have been acquitted (a false positive). A simple probability model of the risk of legal error, presented in Section I, confirms the intuition that prohibiting one side from appealing increases the risk of legal error (the expected total of false negatives and false positives), placing most of the risk on the side that cannot appeal. ${ }^{8}$ Thus, prohibiting government appeals in criminal cases $^{9}$ places most of the risk of legal error on the government.

My ultimate concerns, however, go beyond the apportionment of the risk of legal error. I am especially interested in two additional issues. First, might the prohibition on government appeals-which prevents appellate courts from reviewing claims of pro-defendant trial court error-actually increase total pro-defendant error in the trial courts? Second, might the prohibition affect the evolution of appellate-defined legal standards? Sections II through $\mathrm{V}$ of the article begin to explore how the asymmetry in criminal appeals may distort the perceptions and incentives of both judges and litigants and thereby bias the development and application of standards of law.

Of course, the structure of appellate rights is but one of many possible sources of bias in criminal litigation. The present analysis

\footnotetext{
In discussions of legal error, a false negative (Type I error) means that the acquittal (the "negative") was "false" because it resulted in part from legal error. A false positive (Type II error) means that the conviction (the "positive") was "false" because it resulted in part from legal error. Both terms indicate causation: the legal error was a but for cause of the verdict (i.e., without the legal error the opposite verdict would have resulted). In fact, it is impossible in any particular case to know with certainty whether a given legal error was a but for cause of a jury verdict (or other outcome). The simple risk analysis in section I avoids this uncertainty by assuming that the trial court's ruling on a single legal issue determines the verdict, see text at note 37 (assumption 3). The possibility of "harmless" legal error is discussed in Section V.

A probability analysis of legal error cannot say anything about factual error-the usual context in which false positives and false negatives are discussed-without additional assumptions about the relationship between the facts and the verdict.

- In fact, the prohibition on government appeals in criminal cases is not complete. Although the government may not appeal acquittals, prosecutors in the federal system and in most states may appeal certain other final orders and take certain interlocutory appeals. See notes 44, 46, 133-40 and accompanying text. Because the great bulk of legal issues that arise in criminal cases-including evidentiary issues, criminal procedure issues that arise during trial, and jury instructions-may not be appealed by the government, I refer simply to the "prohibition on government appeals in criminal cases."
} 
shows only that, assuming courts are not otherwise biased for or against defendants, there may nonetheless be a pro-defendant bias in the application and evolution of legal standards. ${ }^{10}$

Many observers of criminal trials believe that courts-judges and juries-are often biased against criminal defendants: hostility toward alleged criminals (by the trial courts) and convicted criminals (by the appellate courts) may lead courts to make findings of fact or reach conclusions of law that favor the government. ${ }^{11}$ The significance of the present inquiry is not vitiated by the fact that there may be pro-government biases in criminal litigation, including conscious anti-defendant prejudice. We must understand any pro-defendant distortion in the law caused by the prohibition on government appeals, even if we ultimately conclude that such distortion merely offsets other, pro-government, bias in the evolution and application of criminal law standards.

Moreover, it is unlikely that the pro-defendant biases identified in this article simply counteract or offset possible pro-government biases. On the contrary, different types of bias may not offset each other or may even be cumulative. Surely the conviction of an innocent defendant because of, say, class bias is one of the most serious errors possible in our system of justice. Yet prohibiting the government from appealing alleged errors of law that result in acquittal does not counteract such bias. A direct means of addressing convictions based on improper considerations would be to require courts, trial and appellate, to undertake an independent evaluation of the evidence and to order an acquittal where an unbiased jury would have found a reasonable doubt. ${ }^{12}$ In short, pro-defendant distortions in the evolution and application of legal standards does not necessarily negate or counteract discrimination against defendants by decision makers in the criminal justice system.

Most importantly, bias in the development and application of legal standards changes the meaning of the law itself, for everyone. This article suggests that asymmetric appeal rights may alter the law through two effects: (1) trial court application of standards of law that are more pro-defendant than required by appellate prece-

\footnotetext{
. The prohibition on government appeals may, in certain circumstances or to a limited degree, introduce a pro-government bias in legal error. See text at notes 71-75, and 98-107.

11 But see also Mirjan Damaska, Evidentiary Barriers to Conviction and Two Models of Criminal Procedure: A Comparative Study, $121 \mathrm{U}$ Pa L Rev 506, 507 (1973) (concluding that, in general, rules of evidence and rules of criminal procedure in common law countries introduce "barriers to conviction").

12 The Supreme Court, in fact, has held that the Due Process Clause imposes such a requirement. See Jackson v Virginia, 443 US 307, 318-19 (1979), discussed in note 114.
} 
dent; and (2) pro-defendant evolution of appellate-defined legal standards. These effects change the content of legal standards for all defendants, all juries, and all prosecutors, whether or not antidefendant discrimination would otherwise lead to an unjust conviction.

Finally, I do not propose permitting the government to appeal claims of legal error when the defendant is acquitted, even on an advisory basis. ${ }^{13}$ Prohibiting the government from seeking a retrial after acquittal furthers two constitutional guarantees: the protection against being "twice put in jeopardy" of conviction" and the right to trial by jury. ${ }^{15}$ But possible by-products of the prohibition on government appeals-pro-defendant distortion in the incidence of the risk of legal error, and pro-defendant bias in the development and application of legal standards-are not fundamental constitutional norms. ${ }^{16}$ It may be possible to permit a greater range of government appeals in criminal cases without undermining ei-

13 In Canada, the appellate court has discretionary power to hear government claims of legal error leading to an acquittal. See Alan W. Mewett, An Introduction to the Criminal Process in Canada 209-12 (Carswell, 1988). Several states had similar rules before Benton $v$ Maryland, 395 US 784 (1969), interpreted the Fourteenth Amendment to include the Fifth Amendment's prohibition on double jeopardy. Even now, at least one state, Kansas, permits the government to appeal from an acquittal to the state supreme court if the legal issue is of statewide interest and vital to the administration of justice. The appellate decision is only advisory, however; even if the government's position is sustained, the trial court acquittal is final. See 22 Kan Stat Ann § 3602(b)(1)-(3) (1988); State v Martin, 232 Kan 778, 658 P2d 1024, 1026 (1983). See also Nevada v Viers, $86 \mathrm{Nev} 385,469$ P2d 53, 54 (1970) (striking down a similar provision on the ground that an advisory appeal presents no case or controversy under the state constitution).

14 US Const, Amend V. The Supreme Court derived the rule prohibiting government appeal of an acquittal from the Double Jeopardy Clause. See cases cited in note 2. Justice Holmes dissented from this analysis, arguing that as long as a case is on direct appeal or is being retried, only one "jeopardy" has attached. Under this view, there is no constitutional distinction between retrial following the defendant's appeal of a conviction and retrial following the government's appeal of an acquittal. Kepner $v$ United States, 195 US 100, 134-37 (1904) (Holmes dissenting). It would seem, however, that one can distinguish between twice being given an opportunity for acquittal, which the Constitution allows, and twice being "put in jeopardy" of conviction, which the Constitution prohibits.

15 US Const, Amend VI. Reversing an acquittal would presume that the acquittal was a "false negative" resulting from an error of law at the first trial. See note 8 . However, the jury may acquit even though it concludes beyond a reasonable doubt that the defendant is guilty; in other words, the jury may exercise its power of "nullification," which is generally understood to be an essential, if implicit, aspect of the right to jury trial. See Jackson $v$ Virginia, 443 US at 317 n 10; United Brotherhood of Carpenters $v$ United States, 330 US 395, 408 (1947). See also Peter Westen, The Three Faces of Double Jeopardy: Reflections on Government Appeals of Criminal Sentences, 78 Mich L Rev 1001, 1012-18 (1980).

16 On the other hand, pro-defendant distortion in outcome error (often called "factual error," see note 6) is an inevitable and hence essential aspect of the constitutional requirement of proof beyond a reasonable doubt. 
ther the double jeopardy prohibition or the right to jury trial. ${ }^{17} \mathrm{My}$ primary purpose here, however, is to consider possible consequences of the present structure of asymmetric appellate rights in criminal cases. Extended discussion of the policy and other implications of this analysis, including proposals for reshaping criminal procedure, must be left for another time.

\section{The Asymmetric Risk of Legal Error in Criminal Cases}

In this section, I construct a simple model of criminal trial and appeal that permits varying assumptions about the objectives and decision strategies of both trial and appellate courts. My analysis is not intended to describe the subjective thought processes of judges; I do not claim that all judges actually regard and respond to precedent in the manner presented. Rather, the analytical structure permits us to begin to understand the significance and possible consequences of asymmetric appeal rights in criminal cases.

$\mathrm{My}$ analysis differs from other models of the litigation process in several respects. I am primarily concerned with judicial decision making (both trial and appellate), not litigant behavior;; I specify the nature and source of judicial error;, ${ }^{19}$ and I examine how judicial uncertainty in the context of asymmetric appellate rights may cause standards of law to shift systematically over time. ${ }^{20}$

\footnotetext{
${ }^{17}$ Proposals to increase the government's appeal rights are briefly discussed in notes $140-42$.

18 Compare Paul H. Rubin, Why Is the Common Law Efficient?, 6 J Legal Stud 51 (1977); George L. Priest, The Common Law Process and the Selection of Efficient Rules, 6 J Legal Stud 65 (1977); George L. Priest, Selective Characteristics of Litigation, 9 J Legal Stud 399 (1980); Robert Cooter and Lewis Kornhauser, Can Litigation Improve the Law Without the Help of Judges?, 9 J Legal Stud 139 (1980); and George L. Priest and Benjamin Klein, The Selection of Disputes for Litigation, $13 \mathrm{~J}$ Legal Stud 1 (1984). Most of my analysis of trial court perception of legal standards is relevant also to litigant behavior, because litigants as well as trial courts "observe" appellate decision making. In addition, strategic litigant behavior is addressed in text at notes 76-82 and in Section IV.

19 Other analyses assume or stipulate different understandings of judicial uncertainty. See Richard S. Higgins and Paul H. Rubin, Judicial Discretion, 9 J Legal Stud 129 (1980); and Ronald A. Heiner, Imperfect Decisions and the Law: On the Evolution of Legal Precedent and Rules, $15 \mathrm{~J}$ Legal Stud 227 (1986).

${ }^{20}$ Other analyses examine legal error (or legal uncertainty), but address different questions. See William Landes and Richard A. Posner, Legal Precedent: A Theoretical and Empirical Analysis, 19 J L \& Econ 249, 271-72 (1976) (legal uncertainty spawns litigation, which in time causes the law to become more precise); Anthony D'Amato, Legal Uncertainty, 71 Cal L Rev 1 (1983) (legal uncertainty increases over time); and John E. Calfee and Richard Craswell, Some Effects of Uncertainty on Compliance With Legal Standards, $70 \mathrm{Va}$ L Rev 965 (1984) (examining the implications of parties' uncertainty as to which legal standards courts will apply).
} 
Although the present analysis concerns the criminal litigation process, in some respects it implicates civil cases as well. ${ }^{21}$ In criminal cases, the prohibition on government appeals causes significant asymmetry in the distribution of disputes on appeal. In some classes of civil litigation, various factors, such as differential stakes, may cause significant asymmetry in the distribution of disputes on appeal. ${ }^{22}$ Any source of asymmetry in the distribution of disputes on appeal can cause differential risk of legal error and distortion in the development or application of legal standards. ${ }^{23}$

\section{A. The Essential Structure of Legal Error ${ }^{24}$}

To illustrate the consequences of asymmetric criminal appeals, I assume that the sole legal issue $e^{25}$ to be decided by the

\footnotetext{
${ }^{21}$ Appellate rights are formally asymmetric in at least one other legal regime, that governing social welfare entitlements. An administrative grant of benefits is not judicially reviewable, while a denial is reviewable. This asymmetry may have profound effects on the amount and allocation of error. See Jerry L. Mashaw, et al, Social Security Hearings and Appeals 136-42, 146-50 (Lexington, 1978); Jerry L. Mashaw, Bureaucratic Justice 148-49 (Yale, 1983); and Jerry L. Mashaw, Disability Insurance in an Age of Retrenchment: The Politics of Implementing Rights, in Theodore R. Marmor and Jerry L. Mashaw, eds, Social Security: Beyond the Rhetoric of Crisis 151, 162-63 (Princeton, 1988). Moreover, administrative acquiescence in an adverse appellate ruling may produce significant asymmetry in disputes on appeal. See Samuel Estreicher and Richard L. Revesz, Nonacquiescence by Federal Administrative Agencies, 98 Yale L J 679 (1989), and note 70.

${ }^{22}$ There may also be asymmetry even for the limited set of criminal issues that the government is authorized to appeal in criminal cases. See notes 134 and 138. For instance, the statute authorizing interlocutory appeal by the government from a pre-trial suppression order requires the United States Attorney to certify that the appeal is not taken for delay and that the evidence suppressed is of substantial significance to the government's case. See 18 USC § 3731 (1982 \& Supp 1989) (excerpted in note 134).

${ }^{23}$ The consequences of asymmetric distribution explored in this article underscore the special nature of the " 50 percent rule" that Professors Priest and Klein derive in their model of the relationship between settled and litigated cases. See Priest and Klein, $13 \mathrm{~J}$ Legal Stud at 1 (cited in note 18). Priest and Klein argue that whatever the initial incidence of disputes in relation to the decision standard, the set of cases actually litigated will, at the limit, be symmetric around the decision standard. Id at 14-15. Their analysis suggests, however, that it is unlikely that symmetry will actually be achieved. Id at 6-30; see also note 49 . The present analysis indicates that unless the set of disputes on appeal is symmetric around the legal standard, further development of the legal standard may be inadvertently biased.

24 The Appendix presents the following analysis of legal error in a more formal, graphic model (see Figures A-1 and A-2).

${ }^{25}$ The voluntariness of a confession may seem like a question of fact as much as one of law, since its resolution requires the court to interpret relevant facts in the particular case. The Supreme Court itself recently despaired of the "elusive," "complex," and "amphibian" nature of the voluntariness inquiry, ultimately holding that for purposes of habeas appeals in federal district courts, the state courts' determination of voluntariness is a "legal question requiring independent federal determination," Miller v Fenton, 474 US 104, 115 (1985). Indeed, the law always is inseparable from the facts, not only where "voluntariness" is at issue but in every legal issue that arises in litigation. I simply have chosen a legal issue for which it is particularly obvious that "law" does not exist apart from application of the law. The
} 
court $^{26}$ in each criminal case is whether the defendant's confession meets the standard of voluntariness required by the Constitution. ${ }^{27}$

For purposes of analysis, we may hypothesize a constructive index of voluntariness: the higher the index value, the more voluntary the statement. At extremely high values, for instance, the defendant walked into the police station and asked for the opportunity to confess. ${ }^{28}$ At very low values, he confessed only after repeated physical beatings or threats to arrest members of his family. ${ }^{29}$ There is some index value that corresponds to the constitutionally required minimum amount of voluntariness. I refer to this index value as the "constitutional standard," or, since it is derived from appellate precedent, the "precedential standard" of law. The appellate court may, over time, shift this standard in a pro-defendant or pro-government direction. All confessions with an index of voluntariness greater than the precedential standard are constitutionally "voluntary," while all confessions with lesser index levels

nominal legal standard (voluntariness) is meaningless unless given content by reference, explicit or otherwise, to situations in which confessions occur (i.e., the "facts"). Despite Miller $v$ Fenton, the United States Court of Appeals for the Seventh Circuit seems to be edging toward reviewing the voluntariness issue as a question of fact, rather than law, at least in habeas corpus cases. See Wilson v O'Leary, 895 F2d 378, 383 (7th Cir 1990), and (in this issue) Comment, Voluntariness of Confessions in Habeas Corpus Proceedings: The Proper Standard for Appellate Review, 57 U Chi L Rev 141 (1990).

${ }^{26}$ The voluntariness issue arises in a procedural context involving only the judge, not the jury. That is, the judge must decide whether a confession meets the constitutional standard of voluntariness. Jackson $v$ Denno, 378 (1964). My injury and analysis apply more generally to all legal issues, however, whatever their procedural context. Is some states, for instance, even if the judge has determined that a confession is voluntary, the jury is permitted to consider its voluntariness (and to exclude an involuntary confession from its deliberations). See Wayne R. LaFave and Jerold H. Israel, I Criminal Procedure $\$ 10.5$ at 799-801 (West, Crim Practice Series ed 1984). Here the legal issue is whether the judge properly instructed the jury on the standard of voluntariness. The judge might explain the meaning of voluntariness by referring either to the facts of the specific case (telling the jury, "If you believe that this-and-that happened, then the confession is voluntary") or to some external reference point (telling the jury, "A confession is not voluntary if it was obtained, for example, by physical brutality"). I posit a legal issue decided solely by the court in order to avoid the procedural complexity of legal issues arising in, for instance, jury instructions.

${ }^{27}$ Since 1936, the Supreme Court has held that the introduction of a defendant's involuntary confession violates his due process rights. Brown v Mississippi, 297 US 278 (1936); and Watts v Indiana, 338 US 49 (1949). Of course, there are other requirements for admission of confessions (Miranda warnings, for example), which for simplicity I ignore in this analysis.

${ }^{28}$ See, for example, Colorado v Connelly, 479 US 157 (1986).

${ }^{29}$ See, for example, Brown v Mississippi, 297 US 278; and Rogers $v$ Richmond, 365 US 534 (1961). Of course, a wide variety of factual considerations contribute to the voluntariness, or involuntariness, of a confession. It is common in economic and policy analysis to collapse such factors into a continuum. Similar abstraction, for instance, underlies the use in economics of "indifference curves." In the voluntariness example, we can always ask the question: Which is more voluntary, this confession or that one? 
are constitutionally "involuntary." Of course, trial and appellate courts do not actually index voluntariness, either for confessions before them or for the constitutional standard. Rather, when a court rules on the admissibility of a confession, it first recounts the underlying facts (for instance, that the defendant was held for two hours by interrogators who misled him and failed to offer him food or coffee). Then the court announces whether such facts demonstrate constitutional voluntariness or involuntariness.

If courts never made errors in implicitly assigning index values to confessions, all confessions with a greater degree of voluntariness than the constitutional standard would be admitted into evidence, while all confessions with a lesser degree of voluntariness would be suppressed. Courts (both trial and appellate) do err, however. ${ }^{30}$ By overestimating or underestimating the voluntariness of a confession, a court will occasionally hold a confession with a voluntariness index below the constitutional standard to be voluntary (committing pro-government error) and occasionally will hold a confession with an index above the standard to be involuntary (committing pro-defendant error). If the actual voluntariness level of a confession is close to the constitutional standard, there is a high likelihood that a court will err. On the other hand, where the actual voluntariness level of a confession either greatly exceeds or falls far short of the constitutional standard, a court will seldom commit legal error. Stated more generally, the likelihood of legal error increases as the distance between the actual index level of a confession and the constitutional standard decreases. When the true voluntariness index level of a confession approaches the constitutional standard (so that the confession is barely voluntary or barely involuntary, relative to the constitutional standard), the probability of legal error approaches fifty percent.

\footnotetext{
30 Because the legal system modeled in this article ascribes authoritative significance to precedent and yet recognizes the possibility of appellate error, it is neither entirely objectivist (insisting on one objectively true answer for every legal issue) nor entirely realist (where there is no "law" beyond the final ruling in each case). See Lea Brilmayer, Wobble, or the Death of Error, 59 S Cal L Rev 363, 389 (1986) ("Methodologically, error cannot exist in the legal system in the commonsensical meaning of the word."). See also Joseph Raz, Legal Principles and the Limits of Law, 81 Yale L J 823, 843-46 (1971) (the "law" provides several correct solutions, rather than a single authoritative answer, to a particular case).

In this article, I do not join the jurisprudential dispute over the coherence of the concept of "legal error" (or, indeed, the concept of "law"). I merely use words such as "legal standard" and "legal error" to refer to particular behavioral constructs. Specifically, as note in the text, the term "precedential standard" refers to that rule of decision implied by previous appellate rulings on the legal issue. The term "legal error" refers to a judicial decision (trial or appellate) that is different from the decision implied by the precedential standard. The precedential standard itself may change over time as appellate courts make rulings that depart from prior precedent.
} 
A critical assumption of my analysis is that legal error in each court, trial and appellate, ${ }^{31}$ is unbiased; any given judge is as likely to overestimate as to underestimate the voluntariness of a confession in dispute, ${ }^{32}$ and therefore is equally likely to err in favor of the defendant or the government. ${ }^{33}$ Although other potential sources of unbiased legal error exist, ${ }^{34} \mathrm{I}$ initially assume, for ease of exposition, that the only source of legal error lies in estimating the implicit voluntariness index of the confession before the court.

\section{B. The Essential Structure of Criminal Trial and Appeal}

Assume:

1. A set of criminal trials in which only one legal issue is disputed: whether the confession the government seeks to introduce is voluntary under the Constitution. ${ }^{35}$ If the trial court rules that the

31 My discussion of judicial decision making assumes that appellate judges, like trial judges, evaluate the voluntariness of every confession de novo, rather than through a Bayesian (conditional probability) approach. Under a Bayesian approach, an appellate judge would first estimate a prior probability of constitutional voluntariness, given that the confession was admitted by the trial court. After reading the briefs, record excerpts, etc., the appellate judge would alter this probability, yielding the posterior (or conditional) probability. In the present context, however, the relative value of the first source of information-the trial court's holding-would appear to be small, compared to the value of considering the facts of the confession. Where the effect of the trial court's holding on the posterior probability of guilt is de minimis, we lose little in ignoring it. Most importantly, as long as the appellate court's error function is unbiased, it does not matter for my purposes whether this function reflects a Bayesian or a de novo evaluation of cases. See also note 71 and accompanying text (distinguishing Bayesian decision making, which is rational and unbiased, from unwarranted appellate deference to the trial court).

${ }^{32}$ The reasons for judicial misestimation may include limits on time, ability, or resources or any other constraints resulting in unbiased but imperfect information.

${ }^{33}$ An alternative way to specify lack of bias is to say that each trial bench and each appellate bench is unbiased on average. Thus, while certain judges on a bench ("liberal" judges?) might tend to assign voluntariness indices that are too low to disputed confessions, other judges ("conservative" judges?) might tend to assign voluntariness indices that are too high. As long as the "liberal" judges are counterbalanced by "conservative" colleagues, the assumption of lack of bias is met.

${ }^{34}$ For example, the trial court might misestimate the voluntariness indices of confessions discussed in appellate opinions, and therefore occasionally misperceive the constitutional standard, but always perfectly evaluate the voluntariness level in the case at hand. As long as such misevaluation of precedent is unbiased-misevaluation in a pro-defendant direction is as likely as misevaluation in a pro-government direction-the analysis does not change. See also text at notes 59-60, discussing another source of unbiased legal error in the trial court.

ss The present analysis concerns only cases where the legal issue of voluntariness is disputed in court. Most cases involving confessions are therefore not relevant for present purposes. These include trials where the defendant does not dispute the voluntariness of the confession, trials where the government decides not to attempt to introduce the defendant's confession, and the largest set of confession cases, those that never go to trial because the 
confession is voluntary, it is admitted into evidence. If the confession is ruled involuntary, it is suppressed.

2. All trials end in acquittal or conviction..$^{36}$

3. If the trial court admits the confession, the defendant is convicted; if the trial court suppresses the confession, the defendant is acquitted. ${ }^{37}$

4. The government cannot appeal from a judgment of acquittal. $^{38}$

5. A convicted defendant appeals. ${ }^{38}$

6. Neither side may take an interlocutory appeal. ${ }^{40}$ Thus, by hypothesis, the prosecution can never appeal an adverse trial decision.

7. When the "voluntariness" issue is raised on appeal, the appellate court either may agree that the confession is voluntary and rule that the trial court did not err, or may conclude that the confession is involuntary and rule that the trial court did err. ${ }^{41}$

8. If the appellate court finds no trial court error, it affirms the conviction. Otherwise, it reverses. ${ }^{42}$

defendant and the government reach a settlement (e.g., the defendant pleads guilty to one or more charges).

${ }^{38}$ This assumption ignores the possibility of a hung jury, which usually results in a new trial, and other causes of mistrial, which may or may not result in a new trial. See note 38 .

${ }^{37}$ The assumption of perfect correlation between resolution of the legal issue and trial outcome is highly implausible for many legal issues, but it is not critical to the analysis and is made solely in order to avoid undue complexity. See note 51 . With respect to the admissibility of a confession, this assumption is, in fact, not entirely unrealistic; the Supreme Court has held that admission of a constitutionally involuntary confession can never be "harmless" error. See note 109.

${ }^{33}$ See note 2. Exactly what constitutes an acquittal is a matter of some debate. The Supreme Court has held that retrial is prohibited after a mistrial that the government provoked for strategic advantage. See Oregon $v$ Kennedy, 456 US 667, 674, 677, 679 (1982). Trial court dismissal of a prosecution for insufficiency of the evidence also counts as an acquittal, even when the finding of insufficiency is attributable to an erroneous legal ruling by the trial court. See United States v Martin Linen Supply Co., 430 US 564, $571-72$ (1977); Sanabria v United States, 437 US 54, 68-69 (1978). However, retrial is permitted after mis-* trials due to a hung jury or other "manifest necessity." See, for example, Illinois v Somerville, 410 US 458 (1973).

${ }^{39}$ In fact, nearly every conviction after trial is appealed in the federal system and many state systems. See Carrington, Meador, and Rosenberg, Justice on Appeal at 60 (cited in note 7) (noting that in some jurisdictions, appeals are taken in up to 90 percent of criminal trials, apparently including in the base number trials that end in acquittal). See also 4 ABA Standards for Criminal Justice, § 21-1.1 Commentary (2d ed 1980) (noting "universal recognition" of every defendant's right to obtain appellate review). Even where appellate counsel for an indigent defendant believes there are no non-frivilous issues on which to appeal, she must advise the appellate court of any conceivable issue. Anders $v$ California, 386 US 738, 744-45 (1967).

${ }^{10}$ But see notes $44-46,134$, and accompanying text.

11 See also note 31 .

12 This is implied by the third assumption, which effectively posits that no error is 


\section{There is one trial court and one appellate court. ${ }^{43}$}

For purposes of analysis, I have assumed that the defendant but not the government can appeal the trial court's ruling. Since 1968, the federal government has, in fact, been permitted to appeal most trial court rulings holding a confession to be constitutionally involuntary. In that year, Congress authorized immediate appeals from pre-trial rulings suppressing evidence, including confessions. ${ }^{44}$ Because defendants are supposed to move to suppress evidence prior to trial, ${ }^{45}$ a trial court ruling suppressing evidence is one of the few legal issues that the government can usually appeal. ${ }^{46}$ Nonetheless, the voluntariness issue is an attractive example for this analysis because it is a one-dimensional, continuous legal standard $^{47}$ and is decided entirely by the court. ${ }^{48}$

"harmless." See note 51. The "harmless error" doctrine on appeal is considered in Section V.

${ }^{43}$ For purposes of the present risk analysis, it does not matter whether more than one judge sits on each court or whether the appellate court sits in panels.

" See Omnibus Crime Control and Safe Streets Act of 1968, § 1301, Pub L No 90-351, 82 Stat 237 (1968), codified at 18 USC § 3731 (1982 \& Supp 1989), and excerpted below in note 134. The consequences of asymmetric appeal rights regarding confessions underscore the significance of Congress's 1968 authorization of federal government appeals from pretrial orders suppressing evidence.

is See, for example, FRCrP 12(b)(3) and 12(f). This rule is not always enforced, however. Trial courts may be reluctant to enforce it because of concern that penalizing the defendant for his counsel's failure to make a pre-trial suppression motion would violate the defendant's constitutional rights. On the constitutional issues see, for example, People $v$ Hampton, 696 P2d 765 (Colo 1985) (vacating trial court conviction where alibi was excluded under Colorado analogue to FRCrP 12(b)(3), and remanding for more articulated basis for exclusion; the trial court's reinstatement of prior judgment after rehearing and application of multi-factor balancing test was affirmed en banc, 758 P2d 1344 (Colo 1988)). And see Taylor v Illinois, 484 US 400 (1988) (permitting enforcement of rule prohibiting defense alibi witnesses not previously disclosed to prosecution).

${ }^{46}$ The scope of prosecutorial appeal rights varies. In all states, specific statutory authorization is required before prosecutorial appeal is permitted. See Arizona v Manypenny, 451 US 232, 249-50 (1981). As of 1984, about half the states permitted government appeals from pre-trial suppression orders. See LaFave and Israel, III Criminal Procedure $\$ 26.3$ at 214 (cited in note 26). Some states have followed the recent federal approach of permitting most government appeals not prohibited by the Double Jeopardy Clause. See id at 211; note 138.

47 I have deliberately selected a legal issue for which there are, theoretically, an infinite number of possible legal standards; that is, voluntariness is a matter of degree and the legal standard specifies "how much" voluntariness is required. See note 29 and accompanying text. Although the voluntariness issue is thus especially suitable for the graphic analysis in this article, the essential logic and conclusions of the analysis apply also to discrete or discontinuous legal standards, such as the meaning of "fraud" under the federal mail fraud statute or the meaning of "premeditation" in a murder statute. My ultimate concern is whether the content or application of legal standards may shift in a pro-defendant direction 


\section{The Incidence of Legal Error}

This section explains why, even if both the trial court and the appellate court are unbiased, there will be an asymmetric distribution of disputes on appeal and more pro-defendant than pro-government error by the appellate court. For aid in explication, this section provides a simple numerical example in footnotes; a graphic model of the asymmetry in risk of legal error is provided in the Appendix.

\section{The distribution of disputes and error at trial.}

To determine the overall risk of legal error in the trial court, we must specify the distribution of disputed confessions in the trial court: What percentage of such confessions is in fact constitutionally voluntary, and what percentage constitutionally involuntary? For ease of analysis, I assume that most disputed confessions have an actual voluntariness level near the constitutional standard and that equal numbers fall above and below the standard. Assuming a symmetric distribution of disputes around the legal standard is reasonable if it is costly-and equally costly-for the defendant and the government to engage in legal disputes. If this is so, the defendant is unlikely to contest confessions with a high degree of voluntariness (relative to the constitutional standard), while the government is unlikely to introduce confessions with low indicia of voluntariness. ${ }^{49}$

The assumptions that the probability of error is symmetrically distributed around the true voluntariness level and that contested confessions are symmetrically distributed around the constitutional standard imply that the trial court will erroneously admit involuntary confessions with the same frequency that it errone-

over time; it makes no difference whether the legal issue is discrete or is collapsible onto a continuum.

48 See note 26.

49 The assumption of a symmetric distribution of disputes in the trial court permits isolation and easy graphic depiction of the asymmetries that result from the rule prohibiting government appeal of acquittals. This assumed symmetric distribution of disputes around the constitutional standard is not realistic in criminal cases, however; it underestimates the relative amount of legal error borne by the government. The distribution of legal disputes that come to trial will be symmetric around the legal standard only if the parties' stakes, cost savings from settlement, and error characteristics are also symmetric. See generally Priest and Klein, $13 \mathrm{~J}$ Legal Stud at 6-30 (cited in note 18); Richard A. Posner, An Economic Approach to Legal Procedure and Judicial Administration, 2 J Legal Stud 399, 41718 (1973). These conditions are unlikely to prevail in criminal litigation. See discussion in text at notes $76-79$. 
ously excludes voluntary confessions. The government and the defendant bear the same risk of legal error at the trial level, ${ }^{50}$ and the number of false negatives (acquittals due to legal error) equals the number of false positives (convictions due to legal error). ${ }^{51}$

\section{The distribution of disputes and error on appeal.}

The government cannot appeal trial court rulings suppressing confessions. On the other hand, we have assumed that defendants appeal all confession rulings in favor of the government. The distribution of cases on appeal is therefore identical to the distribution of confessions admitted (ruled voluntary) by the trial court.

so An example: Suppose that the admissibility of a confession is contested in 1000 cases. Given the assumptions of a symmetric distribution of cases and of unbiased judicial decision making, the trial court will make 500 rulings for the government and 500 for the defendant. Suppose further that the probability of error and the actual distribution of cases are such that the trial court errs in 10 percent of the cases before it. (Of course, as explained in the text following note 30 , more disputes close to the standard will be decided incorrectly than disputes far from the standard.) Given these assumptions, and if there were no appeals, the defense and the government would each bear the risk of legal error in 50 cases.

s1 Continuing the numerical example of the previous note, Box B of the matrix in Table 1 shows false negatives (acquittals due to pro-defendant legal error). Box $\mathrm{C}$ shows false positives (convictions due to pro-government legal error):

Table 1

\begin{tabular}{|c|c|c|}
\hline & $\begin{array}{c}\text { Acquittal } \\
\text { if error-free } \\
\text { trial } \\
\text { (500 cases) }\end{array}$ & $\begin{array}{c}\text { Conviction } \\
\text { if error-free } \\
\text { trial } \\
\text { (500 cases) }\end{array}$ \\
\hline Acquittal & $\begin{array}{l}\text { A } \\
\\
\end{array} 450$ & B \\
\hline Conviction & C & $\begin{array}{ll}\mathrm{D} & \\
& 450\end{array}$ \\
\hline
\end{tabular}

Because we have assumed a perfect correlation between the confession ruling and trial outcome, see text at note 37 (assumption 3), there are an equal number of acquittals and convictions in this numerical example, paralleling the equal number of suppressions and admissions. But the assumption of perfect correlation is not critical. As long as there is a positive correlation for each side between winning the legal issue and prevailing at trial, the government and the defendant will each bear the same risk of legal error, and there will be an equal number of "false negatives" and "false positives." For instance, we may alter the risk analysis to assume that there continues to be a 100 percent likelihood of conviction if the confession is admitted, but only a 50 percent likelihood of acquittal if the confession is suppressed. The percentage of erroneous rulings remains at 10 percent (50 pro-defendant errors and 50 pro-government errors), and the trial court will still admit the confession in 500 cases and suppress it in 500 cases. But the number of convictions increases to 750 , and the number of acquittals drops to 250. As the matrix below indicates, half of the trial court's legal errors are "harmless" (i.e., they do not change the outcome of the case). Compared to the matrix in Table 1, the number of "false negatives" (Box B) and "false positives" (Box C) is halved. 
This distribution of cases is not symmetric around the constitutional standard; it includes many more constitutionally voluntary confessions than involuntary confessions. The confessions on appeal have already been "screened" for voluntariness by the trial court. ${ }^{\text {.2 }}$

Because of the asymmetric distribution of cases on appeal, the appellate court will not make the same number of pro-defendant and pro-government errors. Relatively few confessions on appeal will be below the constitutional standard. The court should reverse the conviction in all of these cases, but sometimes it will erroneously affirm (i.e., hold the confession to be voluntary). These affirmances are pro-government errors. Many more confessions on appeal will be above the constitutional standard. The court should affirm all of these convictions, but sometimes it will erroneously reverse. These reversals are pro-defendant errors. Because we have assumed that judicial error is unbiased, with some probability of error at all points in the distribution (except perhaps the extremes), the asymmetric distribution of cases on appeal will result in more erroneous reversals (pro-defendant errors) than erroneous affirmances (pro-government errors). ${ }^{53}$

Table 2

\begin{tabular}{|c|c|c|}
\hline & $\begin{array}{c}\text { Acquittal } \\
\text { if error-free } \\
\text { trial } \\
\text { (250 cases) }\end{array}$ & $\begin{array}{c}\text { Conviction } \\
\text { if error-free } \\
\text { trial } \\
\text { (750 cases) }\end{array}$ \\
\hline Acquittal & $\begin{array}{ll}\text { A } & \\
& 225\end{array}$ & $\begin{array}{l}\text { B } \quad 25 \\
\quad\end{array}$ \\
\hline Conviction & $\begin{array}{l}\text { C } \\
\end{array}$ & $\begin{array}{ll}\text { D } & \\
& \\
& 725\end{array}$ \\
\hline
\end{tabular}

${ }^{32}$ Continuing the numerical example of Table 1 in note 51 , convictions occur in the 500 cases where the confession was admitted, while acquittals occur in the remaining 500 cases. Of the 500 cases on appeal (all of the convictions), 50 involve confessions with voluntariness levels below the constitutional standard, since the trial court incorrectly admitted these confessions, and 450 involve confessions with voluntariness levels above the standard.

The suggestion from this example that most claims on appeal are not meritorious accords with available data. The author's review of all rulings (published and unpublished) by the United States Court of Appeals for the Second Circuit over a four-month period in 1987 shows that the appellate court found error in 12 percent of the issues it addressed in appeals from convictions, compared with 25 percent of issues addressed in civil appeals. In nearly 8 percent of criminal appeals but less than 2 percent of civil appeals, the appellate court referred to additional legal claims so lacking in merit as not to warrant discussion. Only 7 percent of criminal convictions were reversed in whole or part, compared with 28 percent of civil judgments. See also Carrington, Meador, and Rosenberg, Justice on Appeal at 60 (cited in note 7) (compared to civil cases, a larger percentage of criminal appeals are "wholly lacking in arguable merit.").

${ }^{\text {ss }}$ As long as both the trial court and the appellate court never err more than 50 per- 
At the end of the journey through trial and appeal, the risk of legal error is not apportioned equally between the government and defendants. The government bears the risk of pro-defendant error in the trial court, which it was not permitted to appeal, and it bears the risk of erroneous reversal of convictions as well. The defendant, on the other hand, bears only the risk of erroneous affirmance of convictions. ${ }^{54}$

\section{Selection Effects in Criminal Appeals}

If trial and appellate courts were completely rational and had no constraints on their decision-making resources, the unequal apportionment of legal error in criminal cases would not be of partic-

cent of the time-and if this is not a plausible assumption, we might as well throw darts as have judges-the asymmetric distribution of cases on appeal will result in more pro-defendant than pro-government errors on appeal. A lower percentage of affirmances than reversals will be erroneous, but because a larger number of confessions on appeal are above the constitutional standard, there will be a larger number of erroneous affirmances (pro-government errors) than erroneous reversals (pro-defendant errors). This phenomenon is captured graphically in Figure A-4 of the Appendix.

s4 Continuing the numerical example of note 52, assume, for example, that in 20 percent of cases with actually-involuntary confessions the appellate court erroneously affirms the conviction, while in 8 percent of cases with actually-voluntary confessions the appellate court erroneously reverses. (The reason for the differing probabilities of error is that the set of actually-voluntary confessions contains a smaller percentage of confessions close to the standard, as explained in the previous note.) Of the 500 cases on appeal, there will be 10 (50 $x .20)$ erroneous affirmances (pro-government errors), and $36(450 \times .08)$ erroneous reversals (pro-defendant errors).

Combining these errors on appeal with the risk of error at trial yields the total risk of error borne by each side. The defendant bears the burden of legal error in the 10 cases that the appellate court erroneously affirms. The 36 convictions that the appellate court erroneously reverses will result in new trials at which, by hypothesis, the defendants will be acquitted (because the confessions will be excluded). Hence the government bears the burden of legal error in these 36 cases, in addition to the 50 acquittals resulting from legal error in the original trials. See note 50. As shown in Table 3, the matrix after appeal shows many more false negatives (Box B) than false positives (Box C):

Table 3

\begin{tabular}{|c|c|c|}
\hline & $\begin{array}{c}\text { Acquittal } \\
\text { if error-free } \\
\text { trial } \\
\text { (500 cases) }\end{array}$ & $\begin{array}{c}\text { Conviction } \\
\text { if error-free } \\
\text { trial } \\
\text { (500 cases) }\end{array}$ \\
\hline Acquittal & $\begin{array}{ll}\text { A } & \\
& 490\end{array}$ & B \\
\hline Conviction & $\begin{array}{l}\text { C } \\
\quad 10\end{array}$ & $\begin{array}{ll}\mathrm{D} & \\
& 414\end{array}$ \\
\hline
\end{tabular}


ular analytic interest. The asymmetry in criminal appeal rights would result in relatively more pro-defendant than pro-government errors of law (and, therefore, more erroneous acquittals than erroneous convictions), but standards of law would themselves remain constant, and both trial and appellate courts would, on average, apply the authoritative (precedential) standard of law. In this section and Section IV, I consider how asymmetric appeal rights may cause trial or appellate courts to apply a standard of law that is more pro-defendant than the original precedential standard.

The present section examines several potential "selection effects" produced by the asymmetric distribution of criminal appeals; that is, several ways in which this asymmetry may distort the application or evolution of legal standards in criminal cases. ${ }^{55}$ A selection effect will occur only if there is some source of bias in a court's decision-making process, but this source of bias may be inadvertent, resulting from constraints on a court's decision making capacities. Except for such constraints, I continue to assume that judicial uncertainty and judicial error are unbiased. ${ }^{.6}$

\section{A. Selection Effects in the Trial Court}

A trial court or other observer of appellate opinions must infer the constitutional standard of law from the set of appellate opinions purporting to apply that standard. This task is time-consuming if there are many relevant appellate opinions. The task is also made more difficult by the inconsistency of appellate precedent. This section suggests how resource constraints may introduce a pro-defendant bias in trial court perception and application of the legal standard.

\section{Inferring the legal standard from precedent.}

Appellate precedent is inconsistent because of legal errors made by the appellate court. A given case might be reversed, while other cases with lower apparent voluntariness indices are affirmed.

\footnotetext{
ss A selection effect may be defined as a causal relationship between the distribution of disputes and other variables of litigation. See Priest, $9 \mathrm{~J}$ Legal Stud at 399 (cited in note 18) and Priest and Klein, $13 \mathrm{~J}$ Legal Stud at 1 (cited in note 18). Priest and Klein are concerned with the effect of litigation variables (including the facts, the standard of law, relative stakes, and relative error probabilities) on the distribution of disputes. I consider this type of selection effect, both at trial (see text at notes 76-79) and on appeal (see text at note 52 and notes 49 and 52). I am primarily concerned, however, with the opposite causal relationship: the effect of the distribution of disputes on standards of law.

ss Unbiased in this context means that on average both the trial and appellate courts estimate the correct voluntariness index for confessions. See text at notes 31-34.
} 
Similarly, for any given voluntariness index level, there may be some appellate affirmances (holding the confessions voluntary) and some reversals (holding the confessions involuntary).

The precedential standard is that standard most consistent with the whole range of appellate decisions; that is, the standard that minimizes the number of apparent appellate errors. To derive this correct standard, however, the trial court must estimate the voluntariness index of the confession in every appellate ruling, hypothesize various possible standards of voluntariness, determine the number of appellate rulings inconsistent with each hypothesized standard (ignoring whether an inconsistent ruling implies a hígher or lower standard), and, finally, select as authoritative the standard that minimizes the total number of inconsistent appellate rulings. ${ }^{57}$ At this inferred standard, there are more inconsistent reversals (pro-defendant errors) than inconsistent affirmances (progovernment errors). ${ }^{58}$ Yet any other standard would be inconsistent with a larger number of appellate rulings.

\section{Sampling precedent.}

It is unrealistic to believe that trial courts (or other observers) engage in this costly, complex minimization process. A trial court may reduce its costs of interpreting precedent by considering only a subset of relevant appellate decisions on each legal issue. Such sampling is not necessarily a biased method of decision making. In the context of a distribution of appellate cases that is skewed above the original standard, however, a trial court strategy of sampling precedent will increase the frequency of pro-defendant legal error in final judgments.

Suppose that the trial court considers only a portion of appellate precedent on the issue of the voluntariness of a confession and then applies the standard that minimizes inconsistency among the sampled decisions. Assuming random sampling, the court will on

\footnotetext{
87 In an ideal world, the trial court could admit or suppress the confession in the next case according to the "majority vote," so to speak, of appellate rulings on confessions at that index level. For all indices above the precedential standard, the majority of precedent would be affirmances, and for all indices below the standard, the majority of precedent would be reversals. If there were enough appellate precedent at each voluntariness level, this approach would be equivalent to calculating the legal standard at which appellate inconsistency is minimized. In fact, appellate precedent is not likely to be so complete, and hence the trial court must consider a range of precedent and the standards implied thereby. To be certain in any given case that it is applying the correct legal standard, the trial court must consider the whole range of appellate precedent on the voluntariness issue.

ss See text at note 53 .
} 
average infer the correct standard-the standard actually applied by the appellate court-from the sampled precedent. Sometimes the trial court will infer too low (too pro-government) a standard-where, for instance, the sample contains a disproportionate number of cases in which the appellate court made a pro-government error. In these circumstances, the trial court will apply too low a standard of voluntariness and admit confessions that should be suppressed. These erroneous rulings will be appealable, however, and most of them will be reversed on appeal. (Even if the appellate court also construes precedent by sampling, it will on average infer the correct standard, just like the trial court.) Sometimes, on the other hand, the trial court will infer too high (too pro-defendant) a standard-for instance, where the appellate court made a pro-defendant error in a disproportionate number of decisions in the sample. In this event, the trial court will erroneously suppress additional confessions. These rulings will not be appealable.

The risk analysis in Section I assumed that the only source of error by the trial court is in estimating the voluntariness of confessions. $^{59}$ A strategy of sampling appellate decisions introduces another source of error, one that arises in deriving the constitutional standard from precedent. Assuming unbiased sampling error, the trial court will still derive and apply the correct standard (that implied by all precedent) on average. Yet the trial court's probability of error (of admitting involuntary confessions or suppressing voluntary ones) increases for all voluntariness levels on each side of this standard. Because of asymmetry in the right to appeal these additional trial court errors, the total amount and relative amount of legal error borne by the government increases. This additional pro-defendant bias in the risk of legal error is a selection effect of the asymmetric distribution of disputes on appeal.

Moreover, this pro-defendant selection effect will become stronger over time. An increase in the trial court's probability of error in turn increases the asymmetry in the distribution of cases on appeal, which in turn exacerbates the pro-defendant skew in appellate error, which in turn strengthens the selection effect of sampling precedent. At the limit and absent countervailing correction, the selection effect would increase until half of all constitutionally voluntary confessions were erroneously suppressed by the trial court. ${ }^{60}$

so See text at note 34 .

60 We have assumed that the closer the actual voluntariness level of a confession is to 
3. Balancing instead of minimizing inconsistency in appellate precedent.

We have seen that sampling precedent introduces an additional pro-defendant bias in the risk of legal error, but that it does not bias the trial court's perception of the legal standard. On average, the trial court still perceives and applies the original constitutional standard. We now consider another selection effect of the skew in appellate error, one that may actually cause the trial court to perceive (and apply) a legal standard that is higher-more prodefendant-than the precedential standard.

Subsection one described the complex decision process the trial court must use to infer the correct standard from inconsistent appellate precedent. At the correct standard (that which minimizes total appellate error) there are more inconsistent appellate cases that reverse than affirm; that is, there is more pro-defendant than pro-government appellate inconsistency. Limitations on rational inference, due to cost constraints or to psychological barriers to accurate assessment, ${ }^{61}$ may cause the trial court to be misled by this asymmetry in appellate error. Specifically, bounded rationality may cause a trial court to perceive not the standard that minimizes appellate inconsistency but the standard that balances prodefendant and pro-government inconsistency. The standard that balances inconsistency, however, is skewed above (that is, is more pro-defendant than) the correct standard.

The task of the trial court (or other observer of appellate decisions) is to find the precedential standard. Inconsistent appellate decisions represent a source of uncertainty for the trial court. At any hypothesized standard, there will be some precedent that implies a higher standard (decisions reversing where voluntariness levels are above the hypothesized standard), and other precedent that implies a lower standard (decisions affirming where voluntari-

the constitutional standard, the greater the probability of legal error, so that approaching the standard itself the likelihood of error approaches 50 percent. See text following note 30 . Introducing a new source of legal error increases the court's probability of error for all voluntariness levels and hence the total proportion of wrongly decided cases. But the proportion of wrongly decided cases can never exceed 50 percent, or the court would be better off tossing a coin than seeking to apply the precedential standard. (In terms of Figure A-2 in the Appendix, the probability of error increases on each side of the constitutional standard; at the limit, the probability of error would be a horizontal line at 50 percent for all voluntariness levels.)

62 See generally Amos Tversky and Daniel Kahneman, Judgments of and by Representativeness, in Daniel Kahneman, Paul Slovic, and Amos Tversky, eds, Judgment Under Uncertainty: Heuristics and Biases 84 (Cambridge, 1982). 
ness levels are below the hypothesized standard). The trial court must find a way to account for such inconsistent data.

Balancing is a simple way of accounting. If the trial court can balance every apparent pro-government error with an apparent pro-defendant error, the decisions in effect neutralize each other. The court can then proceed by inferring the standard (the only standard) consistent with all remaining cases. Balancing is an intuitively attractive strategy of decision making because it proceeds by "cancelling out" inconsistent data, permitting the trial court to feel justified in ignoring such inconsistencies.

Like sampling, balancing inconsistent precedent is not necessarily a biased strategy of decision making. Where the distribution of appellate cases on the voluntariness continuum mirrors the appellate court's probability of error for each voluntariness level, a balancing approach will cause the trial court to perceive the correct standard-that actually applied by the appellate court. For every pro-government error made by the appellate court, there will be one pro-defendant error. When, however, appellate disputes and the probability of appellate error are differently distributed, balancing inconsistency becomes a biased method of decision making. ${ }^{62}$

We have seen that in criminal cases the distribution of disputes will be skewed above the constitutional standard, while we have assumed that the probability of appellate error is unbiased (that is, skewed neither above nor below the standard). As a consequence, an appellate court applying the original constitutional standard makes more pro-defendant than pro-government errors. If the trial court engages in a balancing approach, it will derive not this precedential standard (at which total appellate error is minimized) but the slightly higher standard at which apparent pro-defendant and pro-government errors are equalized. At this slightly higher standard, some appellate decisions which in fact were decided correctly are perceived to be pro-government errors, while a lesser number of decisions which were in fact pro-defendant errors are perceived to be correct. The standard that balances inconsistency is that at which a shift in either direction would upset the

\footnotetext{
62 This error in statistical inference that results from balancing appellate error may be understood as an example of the more general phenomenon of erroneously assuming that observations are "representative" of an underlying decision process. See Kahneman and Tversky, Judgment Under Uncertainty at 84-85 (cited in note 61). Because of the skew in the distribution of appellate disputes, appellate outcomes are not "representative" of the appellate court's probability of legal error.
} 
equality between inconsistent appellate affirmances and inconsistent appellate reversals, not that at which a shift in either direction would increase total appellate inconsistency. ${ }^{63}$ The simple numerical consequence of balancing rather than minimizing inconsistency is provided in the footnote; the graphic analysis is provided in the Appendix. ${ }^{64}$

Under this approach to deriving a rule of law from inconsistent precedent, the distribution of appellate decisions is important: there is a selection effect. Because the distribution of confessions on appeal is skewed toward voluntariness levels above the original constitutional standard (due to the rule prohibiting government appeals), the standard perceived from appellate rulings under a balancing approach is also skewed above the original standard.

Eventually, the trial court would apply an extreme pro-defendant standard..$^{65}$ If the appellate court also balances (rather than minimizes) inconsistency, then the precedential standard of law would itself become the extreme pro-defendant standard. In our example, absent a countervailing change in the distribution of disputes or other corrective measures for limiting or reversing selection effects, this extreme standard would require suppression of all confessions. The possible means of counteracting selection effects are discussed in Section III.

${ }^{63}$ Arguably, Professors Tribe and Finkelstein each make this balancing error in proposing a burden of proof in civil cases that equalizes-not minimizes-error for or against plaintiffs. See Finkelstein, Quantitative Methods in Law at 59-104 (cited in note 4); and Tribe, 84 Harv L Rev at 1349 (cited in note 4). See generally note 4.

64 In the numerical example in note 52 , we saw that there are 50 confessions on appeal with voluntariness levels below the constitutional standard, and 450 confessions with voluntariness levels above this standard. If the trial court (or other observer) were able to minimize inconsistency in appellate rulings on these cases, it would infer the constitutional standard. If, instead, the trial court perceives the standard to be that which equalizes prodefendant and pro-government appellate inconsistency, its process of inference will be skewed in the same direction as the distribution of disputes on appeal: eighty-six of the confessions on appeal have voluntariness levels lower than the balancing standard, while 414 have higher voluntariness levels. Hence the standard perceived by balancing is slightly higher (more pro-defendant) than the standard actually applied by the appellate court. See also Figure A-5 in the Appendix.

6s After the trial court perceives a higher (more pro-defendant) standard from recent precedent, it will apply a standard somewhere between the original standard and the higher standard, depending on how much weight it gives recent precedent. The suppression of additional confessions will result in an even greater skew in the distribution of appeals relative to the original standard. (This asymmetry on appeal will be still greater if the distribution of disputed confessions in the trial court changes in response to the new standard being applied by the trial court.) The increased skew in the distribution of cases on appeal will, in turn, produce even greater asymmetry in appellate error-more pro-defendant error than pro-government error. From this next set of appellate rulings, the trial court's perception of the constitutional standard will be even higher than the original standard, and so on ad infinitum. 


\section{B. Selection Effects in the Appellate Court}

We have seen that selection effects may occur in the trial court if, given limits on its decision-making resources, the court samples or balances precedent rather than minimizes appellate inconsistency. Institutional considerations also may lead to selection effects in the appellate court.

\section{Pro-defendant bias.}

Due to the skew in the distribution of appealed confessions, most cases before the appellate court are voluntary relative to the original constitutional standard. All disputed confessions have already been "screened" for voluntariness by the trial court. Yet, because of the unique character of criminal appeals, most findings that a confession was voluntary will nonetheless be appealed. ${ }^{66}$ If the appellate court faithfully performs its function (of applying the constitutional standard), it will usually affirm. The appellate court makes a difference in a distinct minority of cases. Moreover, the better the trial court is, the fewer the number of cases in which appellate review will alter the outcome.

It may be too much to expect that the appellate court's evaluative and decisional processes will be unaffected by these considerations. There are several reasons why an appellate court may depart from a standard of law under which the government usually prevails. First, the court may wrongly conclude that its persistent pattern of affirming indicates that it is applying too low a standard. ${ }^{67}$ Second, and related, because the appellate court does not review those confessions that are suppressed under the present standard, the set of confessions that are relatively involuntary on appeal may come to represent "involuntariness" to the court. ${ }^{68}$

${ }^{6 B}$ See note 39. There are significant incentives for appealing a criminal case that do not exist for civil appeals, including the underwriting of lawyers' costs, see note 76, and certain ethical obligations of defense attorneys, see note 81 .

67 This phenomenon is not unlike an academic faculty, after granting tenure to nearly all its candidates, erroneously concluding that its "standards" have slipped. The opposite phenomenon may also occur: when the faculty denies tenure to a series of candidates, the faculty or observers may erroneously conclude that "standards" have been raised. Of course, it is impossible to know whether standards have changed at all without independently evaluating the strength of each tenure case.

'B Compare Mashaw, et al, Social Security Hearings and Appeals at 139 (cited in note 21) (whereas an administrative law judge (ALJ), who hears many meritless claims, can place each "case in its proper position relative to other cases," the district judge who reviews 
Third, if the appellate court perceives its job to be finding and correcting error, it may become dissatisfied with a standard that results in relatively little error being found. These considerations may lead the appellate court, consciously or unconsciously, to shift the standard in a pro-defendant direction.

An appellate tendency to raise the standard of law may be especially pronounced where the trial court's probability of error decreases over time-as the precedential standard became clearer or as the decision-making resources and quality of the trial bench are strengthened. The appellate court should affirm in an increasing proportion of cases, but will hesitate to do so if it wrongly assumes that trial court decisions are no better than they were previously.

A related, but possibly more intuitive, reason appellate courts may enunciate more pro-defendant standards of law over time is, simply, that this is all they are formally asked to do. ${ }^{69}$ The claim before the appellate court is always that the trial court erred in ruling for the prosecution and against the defendant-that the trial court defined the defendant's rights too narrowly and defined the government's power too broadly. The appellate court does not consider the opposite claim: that the trial court defined the defendant's rights too broadly and interpreted the government's legal authority too restrictively. In every case on appeal, the court is asked to impose a greater restriction on government power than was imposed below. Particularly when reviewing competent trial courts, appellate courts may find it psychologically difficult to grant claims only at a percentage corresponding to the trial court's error rate.

If an appellate court tends to move legal standards in the direction that produces more reversals, criminal standards will be affected more than civil standards. A tendency to reverse operates in favor of the party appealing, which can be either plaintiffs or defendants in civil cases. In criminal cases, on the other hand, such a tendency can only favor defendants.

The dynamic effect of the one-way pressure on appellate courts also tends to move appellate law inexorably in a pro-defen-

\footnotetext{
denials of benefits never "sees the much larger group of stronger claims that ALJs allow"; hence, cases appear stronger on appeal than they would relative to all cases).

${ }^{69}$ Ian R. Macneil makes the point this way:

[The prohibition on government appeals] results in an imbalance whereby reviewing courts are under steady, relatively one-way demands to change or implement criminal law in directions favouring the criminal defendant.... It is difficult to believe that over a period of time this leaves the substance of legal development unaffected.

A View from the South, 7 Can Bus L J 426, 437-38 (1982-83).
} 
dant direction. Suppose that the appellate court imposes a significant pro-government change in the legal standard. Convicted defendants will routinely appeal trial court rulings implementing the new standard, providing the appellate court with opportunities to rethink the change in the law or at least to adjust the standard in a less pro-government direction. But if the appellate court imposes a significant pro-defendant change in the law, the government cannot appeal trial court rulings implementing this new standard. Indeed, the only appeals raising the issue will be by defendants urging the court to reassert the new standard or move it even further in the pro-defendant direction..$^{70}$ As a result, we may expect appellate courts more readily to undo pro-government than pro-defendant changes in the law.

\section{Pro-government bias.}

A complete examination of the possibility of selection effects due to asymmetry in the distribution of appeals must acknowledge the possibility that appellate courts exhibit the opposite bias-a tendency to affirm rather than reverse convictions-because of a policy or practice of appellate deference toward the legal evaluations of the trial court. ${ }^{11}$ There is some empirical evidence of such deference, in both civil and criminal cases, from appellate opinions that defer to trial court "discretion" on various issues of law. ${ }^{72} \mathrm{Ap}$ pellate deference is particularly evident in matters relating to admission of evidence and conduct of trial..$^{73}$

70 A similar "one-way ratchet" on changes in legal standards has been attributed to the principle that federal agencies should "acquiesce" in an adverse appellate ruling. See Estreicher and Revesz, 98 Yale L J at 744 (cited in note 21) ("[A] total bar against intracircuit nonacquiescence would make it impossible for a circuit that at one time ruled against the agency to continue a dialogue with circuits that subsequently ruled for the agency. . . . [O]nly the circuit that ruled for the agency would be open to possible reconsideration of its position. ... [T] [Te one-way ratchet moves exclusively in the direction of disapproval of the agency's action."). See also id at 738-39, 741 and note 32 (even more powerful "one-way ratchet" would occur under a regime of intercircuit nonacquiescence).

71 I refer to unwarranted deference, not to a Bayesian reassessment of the voluntariness of a confession that takes into account the trial court's assessment. See note 31 .

72 See generally Joseph Sneed, Trial Court Discretion: Exercise by Trial Courts and Review by Appellate Courts (unpublished presentation before the judges of the Second Circuit, Yale Law School, 1982). Judge Sneed's unusually informative survey of Volumes 658 and 659 of the Federal Reporter (Second Series) indicates that the appeals courts scrutinized trial court discretion in about one-quarter of all cases, and approved the exercise of discretion over two-thirds of the time.

${ }^{73}$ See, for example, United States $v$ Lee, 846 F2d 531, 534 (9th Cir 1988). Appellate deference to a trial court's legal evaluations is related to but must be distinguished from appellate deference to trial court factfinding. Most appellate systems in this country have explicit rules requiring appellate courts to adhere to trial court findings of fact that are not 
Because all trial rulings reviewed in criminal appeals were decided in favor of the government, an appellate tendency to affirm would increase the appellate court's pro-government error. ${ }^{74}$ If observers (including the trial court) do not recognize and adjust for any such tendency, ${ }^{76}$ they will infer from appellate decisions a constitutional standard below the original standard. If the appellate court defers in each successive round of appeals, the apparent precedential standard of law could continually shift in a pro-government direction, absent countervailing bias or correction, as discussed below.

\section{Counteracting Selection Effects}

It would be difficult to test for the existence of selection effects in criminal cases. We cannot know the extent to which trial and appellate courts (and other legal observers, most importantly litigants) are aware of the asymmetric distribution of criminal appeals and account for such asymmetry in deriving and applying the standards of law. It would be a great leap of faith, however, to assume that the asymmetry of disputes on appeal and the asymmetry of appellate error have no effect on criminal law standards over time.

To avoid any selection effect, the trial court (and future appellate courts) must understand that the pro-defendant skew in apparent appellate error (more erroneous reversals than affirmances) is not indicative of an underlying pro-defendant shift in the standard applied by the appellate court. Additionally, the appellate

\footnotetext{
"clearly erroneous." See, for example, FRCP 52(a). Unlike deference toward trial court factfinding, which affects only the outcome of the particular case, deference toward legal evaluations may affect the development of substantive standards of law.

Judge Sneed, in the unpublished manuscript cited in note 72, suggests that deference to the legal evaluations of the trial court may often be inappropriate (for instance, in determining the scope of constitutional rights or in interpreting statutes), but is sometimes quite appropriate (for instance, in determining whether a juror should have been dismissed or whether the identity of a confidential informant should have been revealed). Sneed, Trial Court Discretion at 3-6.

74 In civil cases, where there is a symmetric appellate distribution because either side can appeal, a policy of deference toward the trial court will increase both pro-plaintiff and pro-defendant error. In criminal cases, however, a policy of deference increases only the appellate court's probability of pro-government error. In my example, the appellate court will be more likely to affirm admission of confessions with actual voluntariness levels below the constitutional standard, and will be less likely to reverse admission of confessions with voluntariness levels above the constitutional standard. (The error characteristic for the appellate court in Figure A-2 in the Appendix would be symmetric not around the original standard, but around an index level lower than the original standard.)

${ }^{75}$ See text at notes $89-91$.
} 
court must be willing to continue to apply standards of law under which the government usually prevails. Finally, in inferring the precedential standard, legal observers (including trial and appellate courts) must be prepared to discount for any appellate deference to the legal evaluations of trial courts.

Even if courts are not fully able to gauge and adjust for appellate asymmetry on a case-by-case basis, there are several ways in which such effects may be tempered or even entirely counteracted. This section examines how litigating attorneys (defense counsel and prosecutors) and courts (trial and appellate) may respond to the possibility of selection effects. First, counsel may respond strategically by seeking to alter the distribution of disputes that come before courts. Second, trial and appellate courts themselves may engage in periodic self-correction. Third, the effective range of disputes considered by the appellate court might be expanded through irrelevant argument to the appellate court or dicta in appellate opinions. Finally, there may be exogenous correction by a lawmaking institution, such as the Supreme Court or a legislature, which is usually outside the system of criminal trial and appeal.

\section{A. Altering the Distribution of Disputes}

If repeat litigants in criminal cases are aware of possible selection effects, they have an incentive to alter the distribution of disputes on appeal. In particular, the possibility of pro-defendant selection effects resulting from a skewed distribution of disputes on appeal may lead prosecutors to attempt to counteract this skew by asserting meritless claims in the trial court. In order to understand the significance of this incentive, it is helpful first to consider the incentives operating on defense counsel and prosecutors in the absence of selection effects.

\section{The distribution of disputes without selection effects.}

Even apart from consideration of selection effects, defense counsel risk little by disputing all available legal issues at trial and on appeal, even where the claim appears to have little merit. Defense counsel's primary disincentives to dispute legal issues are litigation $\operatorname{costs}^{76}$ and the consequences of irritating the court (or

${ }^{76}$ The state pays the direct legal costs of defendants classified as indigent. According to federal statistics, indigent defendants constitute approximately 75 percent of all defendants in the federal system. Mark Silver, Statistics Division of the Administrative Office of the United States Courts (communication with author, December 19, 1989). The opportunity 
jury). ${ }^{77}$ In terms of our example, the defense has little to lose in trying to suppress even confessions with unmistakable indicia of voluntariness. If a clearly voluntary confession is (erroneously) suppressed at trial, the likelihood of acquittal increases, and the defense does not face the prospect of reversal inasmuch as the prosecution cannot appeal. Even if the trial court refuses to suppress the confession, the defense can raise the issue on appeal and may possibly win reversal (if the appellate court errs). ${ }^{78}$ Once the decision has been made to take an appeal, the incremental costs in raising a meritless claim are relatively low. Because we may expect the defense to dispute a legal issue even when it considers the likelihood of prevailing to be low, the set of disputes in the trial court will include a fair number of confessions whose actual voluntariness is far above the constitutional standard.

Raising a legal claim of dubious merit imposes greater costs on prosecutors, so that (apart from strategic response to the possibility of selection effects) we would expect the government to assert fewer claims that it is likely to lose. In addition to litigation costs and the consequences of irritating the court, the prosecution has another significant disincentive to disputing a legal issue at trial: the possibility of reversal if it prevails in the trial court. ${ }^{79}$ The specter of reversal is greater, of course, the more frivolous the government's legal claim. Hence, we would not expect the prosecution

costs of litigating a particular case may be significant even for public defenders and other court-appointed attorneys, however.

77 Indeed, because defense counsel do not face the threat of reversal, there are few structural incentives to adhere fully to rules of evidence and procedure. Even after the court rules against defense counsel on an evidentiary issue, the threat of contempt is the major disincentive to further disputation. See, for example, William Glaberson, Lawyers and Judges Clash Over Contempt Citations, NY Times B3 (May 19, 1989) (describing criminal trial in New York City in which a defense lawyer was held in contempt by U.S. District Judge Constance Baker Motley for making impermissible arguments to the jury; Judge Motley explained, "There has to be some way to get lawyers to obey the direct orders of the court."). In civil cases, monetary sanctions may be imposed for making claims known to have no merit. See, for example, FRCP 11.

${ }^{78}$ See note 39 (nearly all criminal convictions are appealed).

79 Reversal for insufficiency of the evidence results in outright acquittal. See Burks $v$ United States, 437 US 1, 17-18 (1978). Generally, however, reversal for legal error results in retrial. See United States v Ball, 163 US 662, 672 (1896); United States v Tateo, 377 US 463 (1964). A retrial entails litigation costs and the possibility of acquittal. The likelihood of acquittal is greater at the retrial because the pro-government error will not be repeated. Additionally, the likelihood of conviction changes because witnesses disappear, their recollections fade, and each side knows more about the other's strategy and has more grist for impeachment. These factors usually work in favor of defendants because the government bears the burden of proof and the defense usually has few witnesses or other evidence in criminal cases. 
to seek to introduce many confessions with low indicia of voluntariness; even if the confession were (erroneously) admitted at trial, the resulting conviction would likely be reversed on appeal. ${ }^{80}$

The foregoing analysis suggests that Section I's simplifying assumption of a symmetric distribution of disputes in the trial court is unrealistic. Rather, we should expect the distribution in the trial court to be skewed above the constitutional standard, because the defendant is likely to contest confessions with a high degree of voluntariness (relative to the constitutional standard), while the government is less likely to seek to introduce confessions with low indicia of voluntariness. The consequences of a trial court distribution skewed above the constitutional standard are that: (1) the government will prevail in most disputes in the trial court; (2) the distribution of appellate disputes will be even more skewed above the constitutional standard than indicated in Section I; (3) the relative proportion of pro-defendant appellate error will be even greater; and (4) the strength of the pro-defendant selection effects previously identified will be magnified.

2. Strategic response to selection effects.

Litigants (or at least attorneys) who are aware of the potential for selection effects have an incentive to alter the distribution of disputes on appeal by raising additional claims of dubious merit in the trial court. Every time a defendant loses the motion to suppress a voluntary confession and raises the issue on appeal, the distribution of cases on appeal is further skewed above the constitutional standard, and resulting pro-defendant selection effects are strengthened. Conversely, if the prosecution succeeds in introducing an involuntary confession in the trial court and the defendant raises the issue on appeal, the asymmetric distribution of disputes on appeal (i.e., the skew above the constitutional standard) is reduced, thereby dampening the pro-defendant selection effects previously identified.

For the individual defense attorney or prosecutor, the marginal benefit from incrementally altering the distribution of disputes on appeal is not likely to be great. The contribution of any one case to the distribution on appeal is insignificant, and any benefi-

so The possibility that trial court legal error might be deemed "harmless" by the appellate court, and thus not warrant reversal, marginally reduces the prosecution's disincentive to raising non-meritorious claims. See Section V. In any event, however, the harmless error doctrine does not apply to admission of constitutionally involuntary confessions. See note 109. 
cial consequences from strengthening or weakening pro-defendant selection effects are entirely prospective. The selection effect incentive is thus greatest for attorneys (defense counsel or prosecutors) who handle large numbers of criminal cases on a continuing basis.

Even for individual attorneys who repeatedly engage in criminal litigation, however, it is unlikely that the selection effect incentive will result in the assertion of many additional claims. There is a free rider problem: any benefit from altering the distribution of disputes on appeal will be widely dispersed among all defense counsel or all prosecutors. It is in the interest of the class of defense attorneys and the class of prosecutors to alter the distribution of cases on appeal by raising some claims that would otherwise be too frivolous to pursue, but litigation costs severely reduce the incentive of any individual attorney to undertake this effort.

Prosecutors would appear better situated than defense counsel to develop and enforce a mechanism for promoting their class interest. Prosecutorial offices are ready-made cartels in each judicial district. ${ }^{81}$ Conceivably, each office could determine the optimal strategic response to selection effects and then bureaucratically enforce such a strategy by requiring individual prosecutors to bring certain claims that would not otherwise be pursued. For the prosecutorial office as a whole, the resulting diminution in the prodefendant skew of appellate disputes and appellate error may well offset the present adverse consequences (i.e., the expected costs of litigation, possibly irritating the court, and possible reversal and retrial) of pursuing marginal claims. ${ }^{82}$ Even if such a strategic response would not be great enough to eliminate asymmetry in the appellate distribution of cases, it would at least temper the prodefendant selection effects produced by the asymmetric appellate structure in criminal cases.

81 It is possible, of course, that defense attorneys might engage in non-explicit but consciously parallel strategic responses to selection effects. Moreover, one may view ethical strictures on the criminal defense bar as encouraging claims that lack merit, but benefit defense attorneys as a class by increasing the asymmetry in the distribution of cases on appeal and producing pro-defendant selection effects. See, for example, 4 ABA Standards for Criminal Justice, \$21-1.1, Commentary (cited in note 39); Anders v California, 386 US 738; and ABA Model Rule of Professional Conduct 3.1 (1987) ("A lawyer shall not bring or defend a proceeding or controvert an issue therein, unless there is a basis for doing so that is not frivolous. . . . A lawyer for the defendant in a criminal proceeding . . . may nevertheless so defend the proceeding as to require that every element of the case be established.").

82 It would be difficult to prove the existence of such a strategy. Whenever the prosecution argues to a trial court that the precedential standard of law should be altered, it is implicitly acknowledging that its legal position is not meritorious under the present standard. In making such a claim, the prosecution seeks to alter the distribution of disputes that will come before the appellate court. 


\section{B. Self-Correction of Selection Effects}

If the legal standard applied by the courts continues to evolve over time in either a pro-defendant or pro-government direction, the trial or the appellate court might notice a significant change in the law and attempt to correct it. Self-correction does not require a court to understand the nature or cause of the shift in the legal standard; the court need only recognize that the standard is significantly higher than it used to be and resolve to apply the previous standard. Much self-correction can be achieved without any change in the basic structure of judicial decision making. The appellate court can expressly overrule its own recent decisions, and either court can give greater weight to distant precedent than to recent precedent.

Significantly, however, where the pro-defendant shift in the standard occurs only at the trial court level, and the trial court does not correct itself, appellate court rulings applying the correct standard will not be sufficient to get the trial court back on track. As the standard applied by the trial court shifts further-in a prodefendant direction, the trial court will suppress more confessions. Defendants will appeal only confessions that are admitted under this shifted standard-confessions with high levels of voluntariness. The appellate court, applying the correct standard, will simply affirm almost all cases. This analysis suggests that maverick trial court judges who refuse to apply the perceived legal standard are critical to the judicial decision-making process in criminal cases. $^{83}$

\section{Irrelevant Appellate Argument and Appellate Dicta}

In criminal cases the government often engages in a strategy that counteracts, to some extent, the asymmetric distribution of disputes before the appellate court. The government knows that the appellant's briefs and claims of error on appeal will show the appellate court only instances in which the trial court ruled in favor of the government. ${ }^{84}$ To counteract the impression that the

\footnotetext{
${ }^{83}$ For a slightly different statement of this point, see text at note 136 .

${ }^{84}$ Of course, if the appellate court reads the entire record in a case, it will discover claims decided adversely to the prevailing party. Generally, however, the readily available record on appeal (contained in appendices to the briefs) includes only portions relevant to the appealed claims.
} 
trial court might have been biased against the defendant, the government's response brief often cites adverse trial court rulings. For instance, the government might mention that the trial court excluded a government witness, permitted cross-examination of another witness that the government had urged was tangential, or included a limiting instruction opposed by the government. ${ }^{85}$ Whatever its motivation, this style of responsive argument expands the range of disputes about which the appellate court is informed.

In terms of our example, the appellate court rules only on disputed confessions that the trial court has allowed into evidence. There are other cases, however, where the trial court suppressed confessions. If these other cases end in conviction, various legal issues will be raised on appeal, and in its response briefs on these other issues the government may note that the trial court ruled against it on the confession issue. This practice alters the distribution of contested confessions that come to the attention of the appellate court to include a greater number of cases where the confession is below the constitutional standard. The appellate court is thereby explicitly informed that many disputed confessions are suppressed under the present standard of law, and this knowledge may counteract any tendency by the court to raise the standard.86

The appellate court itself may attempt to counteract the asymmetry in criminal appeals through strategic use of dicta in its opinions. Suppose that for every issue on appeal the appellate court not only describes the factual context and ruling for the claim at hand, but also provides a hypothetical fact situation on which it would rule differently. For instance, the court might rule that the confession in the present case is constitutionally voluntary, but note that if some fact or set of facts were different, the confession would be held involuntary. In effect, every appellate decision would simultaneously affirm and reverse through the use of

\footnotetext{
${ }^{85}$ See, for example, Government's Brief in Response at 21, in United States $v$ D'Amato, No 83-1097 (2d Cir 1983) (trial court refused to permit government to call certain witnesses); Government's Brief in Response at 31 in United States $v$ Gilboe, No 81-1481 (2d Cir 1982) (noting that appellant had failed to mention that trial court granted defense request for adjournment of trial); Government's Brief in Response at 54-55 in United States $v$ Ferrara, No 82-1127 (2d Cir 1983) (noting that court twice refused to restrict defense counsel's cross-examination before finally doing so); Government's. Brief in Response at 30, United States v Levy, No. 88-1062 (2d Cir 1988) (presenting statistical table of trial court rulings in favor of the defendant during the testimony of a key government witness, in response to defendant's argument on appeal that the trial court had acted improperly in itself questioning witness).

${ }^{86}$ See text at notes $67-70$.
} 
dicta, though one ruling would be an affirmance or reversal of a hypothetical case. ${ }^{87}$ Just as most actual disputes are above the legal standard, most dicta would pertain to hypothetical disputes below the standard, thereby counteracting the asymmetry that results from the prohibition on government appeals.

As odd as this may sound when stated so explicitly, it is not unusual for appellate opinions to follow this form, suggesting circumstances in which the appellate ruling would be different or specifying the limits of the court's reasoning. ${ }^{88}$ Observers of appellate opinions thus have an enlarged number of data points from which to infer the precedential standard, and a range of appellate decisions (real or hypothetical) that is more symmetrically distributed around the constitutional standard. This analysis of the value of dicta suggests that a court may more effectively perform its lawdeclaring function when it not only rules on the particular legal issue before it but also indicates the limits of its ruling.

Explicit acknowledgment by the appellate court of the occasions on which it is deferring to the legal evaluations of the trial court may also curtail a pro-government selection bias. ${ }^{89}$ If the appellate court signals in its opinion that it is deferring to the trial court on a close issue of law, observers are able to discount the decision's precedential significance. Observers will infer the precedential standard not from the formal ruling, which affirms the trial court, but from the implicit ruling absent appellate deference. Indeed, the evidence that suggests appellate courts often defer to

87 This category of dicta (hypothesizing a converse case) must be distinguished from dicta of another sort: where the court decides a case on one ground (for instance, on a procedural issue) but includes in the appellate opinion a discussion and (in effect) an advisory ruling on some other ground (for instance, a substantive question of law). See, for example, New Era Publications International v Henry Holt \& Co., 873 F2d 576, petition for reh'g denied, 884 F2d 659 (2d Cir 1989) (appellate court affirmed ruling in copyright infringement case in favor of defendant on ground that plaintiff's suit was barred by laches, but included fifteen page discussion concluding that defendant had violated copyright law). Such dicta does not counteract the effects of asymmetry in the distribution of appellate cases.

${ }^{88}$ See, for example, United States v Valencia, 826 F2d 169, 173 (2d Cir 1987) (holding that in this case government could not introduce statements made by defense counsel in effort to secure bail, but indicating that such admissions could be introduced when critical to proving element of crime); United States v Camarata, 828 F2d 974, 978 (3d Cir 1987) (intimating that court would rule differently under specified different facts); United States v Thomas, No 89-1262, slip op at 1013 (2d Cir, Jan 8, 1990) (noting what additional facts would be needed to sustain government's claim of exigent circumstances dispensing with need for warrant); United States v Fornaro, No 89-1306, slip op at 1101 (2d Cir, Jan 11, 1990) (suggesting what types of additional facts would be needed to sustain claim).

s9 See text at notes 71-75. 
trial court legal evaluations ${ }^{20}$ also suggests that such deference does not lead observers to infer too pro-government a standard from such precedent. An explicit policy of deference increases the total amount of pro-government appellate error, but will not impart a continuous pro-government bias in the standard implied by appellate decisions. Consequently, a policy of deference to trial courts serves as but a limited brake on the pro-defendant biases identified previously. ${ }^{91}$

\section{Exogenous Correction of Selection Effects}

If correction occurs at neither the appellate nor the trial court level, evolution of the legal standard in either a pro-defendant or a pro-government direction may be tempered or reversed by exogenously imposed corrections, such as statutory clarification or Supreme Court rearticulation of the original standard. Indeed, the Supreme Court's continuous review of petitions for certiorari permits it to keep abreast of unwarranted evolution of legal standards in the lower courts, and its discretionary jurisdiction allows it periodically to step in and re-adjust standards of law.

\section{Incentives for Trial Court ERror}

We have thus far assumed that the trial court has only one objective: to apply the legal standard derived from appellate precedent. The previous sections showed that even under this assumption, the structure of criminal appeals may cause perception or application of the legal standard to evolve in a pro-defendant direction.

If we relax the assumption that the trial court seeks only to apply the precedential standard, additional biases are introduced. In particular, if the trial court also seeks to avoid reversal, the prohibition on government appeal of acquittals provides an incentive to make pro-defendant errors. This incentive may conceivably be

\footnotetext{
so Judge Sneed's survey of Volume 658 of the Federal Reporter (Second Series) found, that in 60 percent of the cases where the appellate court scrutinized trial court discretion, the appellate court explicitly stated that the standard of review was "abuse of discretion" or some variant thereon, while in the remaining 40 percent of cases the abuse of discretion standard was applied sub silentio. Sneed, Trial Court Discretion (cited in note 72); see also notes 72 and 73.

${ }^{91}$ In this way, an appellate tendency to affirm is like the "harmless error" rule, discussed in Section V: 1) it increases total uncorrected pro-government error, but it does not necessarily change the legal standard implied by appellate precedent; and 2) it reduces the pro-defendant bias that would otherwise result from a trial court objective of avoiding reversal. See text at notes 119-21.
} 
limited in some circumstances by a competing incentive to preserve legal rulings for appellate review.

\section{A. Reducing the Risk of Reversal}

Judges do not like to be reversed. ${ }^{92}$ In civil cases, the trial court always bears some risk of reversal, because every legal issue is potentially appealable by the losing party. In civil cases, therefore, when the trial court does not know which party will prevail, a trial court seeking to avoid reversal will apply the precedential standard, so long as the appellate court is expected to continue to apply that standard..$^{93}$

In criminal cases, on the other hand, the trial judge can completely avoid any risk of reversal by ruling against the government. In a system that absolutely bars any prosecution appeals, even by mandamus, ${ }^{94}$ a trial court seeking to minimize reversal would rule for the defendant on all contested legal issues. If the trial then ended in acquittal (and, presumably, ruling for the defendant would increase the likelihood of this outcome), the legal issues could not be appealed. If the trial ended in conviction, the defendant would have nothing to appeal, since he prevailed on all legal issues below. ${ }^{85}$

The trial court would adopt the extreme practice of always ruling for the defense only if its sole objective were to avoid risk of reversal. Of course, trial courts have other objectives and concerns. First, there is the possibility of mandamus, which is even more injurious to reputation than is reversal. If a trial court applied an extreme pro-defendant decision rule, the appellate court could be expected to issue writs of mandamus enjoining such rulings. More-

\footnotetext{
92 Most participants in and observers of trial courts perceive reversal to be a major concern of trial judges. See Higgins and Rubin, $9 \mathrm{~J}$ Legal Stud at 130 (cited in note 19); and Richard A. Posner, Economic Analysis of Law 506 (Little, Brown, 3d ed 1986).

os A trial judge who knows which party ultimately will prevail at trial-a more likely phenomenon in bench, as opposed to jury, trials-can avoid reversal by always ruling against that party on legal issues. More generally, in civil and criminal cases alike, the trial court reduces the risk of reversal by ruling in favor of the side that is likely to lose in the trial court.

" Mandamus is an extraordinary interlocutory writ which the appellate court may issue against the trial court in order to enjoin egregious error, even though the party seeking the writ has no right to interlocutory appeal. See FRAppP 21.

${ }^{93}$ As Glanville Williams succinctly explained, "In an effort to minimize this danger [of reversal of conviction], the trial judge will incline to exclude relevant evidence for the prosecution where its admissibility is doubtful, while giving great latitude to the defence. This one-sided treatment of the evidence itself helps to secure acquittals." The Proof of Guilt at 327 (Stevens \& Sons, 3d ed 1963).
} 
over, the trial court's own conception of its role as a tribunal bound by appellate law, its desire for fairness or justice in particular cases, and, ultimately, the fear of disciplinary action or removal make indulgence in such an extreme practice unlikely.

Nevertheless, a trial court's desire to avoid reversal may have profound consequences in criminal cases. Trial courts can significantly reduce the risk of reversal through a decision rule far less extreme than the one described above. The trial court can rule for the defense on all questions of law that are "close"-where, in the trial court's view, the prosecution barely meets the legal standard. Under this approach, the trial court will apply a standard of law that is slightly higher (more pro-defendant) than the precedential standard. As the trial court applies a higher standard, it will admit fewer confessions, meaning that fewer disputes will be appealed and the appellate distribution will be more skewed above the original standard. One may believe that a judge who succumbs to fear of reversal by deliberately erring for the defense is not acting properly. ${ }^{96}$ Whatever one's distaste for this topic, however, the incentive to favor the defense is an unavoidable consequence of asymmetry in criminal appeals, ${ }^{97}$ and it should not be ignored in evaluating our present structure of criminal litigation.

\section{B. To Avoid Reversal or to Avoid Uncorrected Error?}

Professor Mirjan Damaska has pointed out that in criminal cases there may be an opposing-pro-government-bias if "judges tend to rule in favor of the prosecution in close cases so as to preserve reviewability of their rulings."98 Preserving reviewability also preserves reversibility. Hence the tendency hypothesized by Professor Damaska is at odds with the tendency discussed in the preceding section.

a This point has been made elsewhere with greater vigor. See Justin Miller, Appeals by the State in Criminal Cases, 36 Yale L J 486, 511 (1927) ("The weak, spineless trial judge is able to hide his weakness in a record upon which the state has no appeal."); and Lester B. Orfield, Criminal Appeals in America 55-76 (Little, Brown, 1939) (arguing, inter alia, that "the kind of judge who rules for the defendant merely to play it safe has no place on the bench," id at 75).

${ }^{97}$ Justin Miller also acknowledged: "As a matter of practice and experience, it can fairly be said that some trial judges do undoubtedly and deliberately weigh the scales in favor of the defendant. Such a judge knows that if he rules for the defendant on all doubtful points and gives every instruction offered to him, he will be safe from reversal."Appeals by the State in Criminal Cases, 36 Yale LJ at 511 (cited in note 96). See also id at 508-11 (discussing other aspects of "demoralization" caused by one-sided appeals).

${ }^{28}$ Damaska, $121 \mathrm{U} \mathrm{Pa} \mathrm{L} \mathrm{Rev} \mathrm{at} 520 \mathrm{n} 22$ (cited in note 11). As fas as I am aware, Professor Damaska is the first to note the possibly competing incentives for pro-defendant and pro-government error, both resulting from the asymmetry in appeal rights. 
A trial court will seek to preserve a legal issue for appellate review if the appellate court is less likely to err than the trial court $^{99}$ (or, at least, the trial court believes it is), ${ }^{100}$ and the trial court wants to avoid the injustice of uncorrected legal error affecting a final judgment. The only way the trial court can preserve an issue for appellate review in a criminal trial is to rule for the government. Of course, just as the trial court would never adopt the extreme practice of minimizing the risk of reversal by ruling for the defendant on all contested legal issues, so it would never adopt the extreme approach of minimizing the risk of uncorrected legal error by always ruling for the government. Adoption of such an extreme decision rule is quite inconsistent with the trial court's conception of its role in a hierarchical system and its commitment to the rule of law.

The rule prohibiting government appeals, then, creates an incentive for pro-defendant bias if the trial court seeks to avoid reversal, and an opposing incentive for pro-government bias if the trial court seeks to avoid error in final judgments. In order to determine which of these opposing tendencies is stronger, let us suppose that the trial court pursues all three objectives identified in this article: applying the precedential standard of law (the primary objective), avoiding reversal (a competing secondary objective), and avoiding uncorrected legal error (another secondary objective). Graphic depiction of a hypothesized distribution of cases in the trial court, Figure I below, ${ }^{101}$ will aid in examining the interaction of these incentives.

\footnotetext{
"P An appellate court might be less likely to make legal errors than a trial court because appellate judges have more resources (time, staff, and soon) to invest in arriving at correct rulings, and because appellate courts usually sit in panels of three or more judges.

It might be thought that there is no reason for a system of appeal unless the risk of legal error is less on appeal than at trial. In fact, the decision whether to have a system of appeal is more complicated than simply comparing error rates in the trial and appellate systems. In addition to its role in correcting legal error, an appellate court may ensure some uniformity in error. If the nature of legal error is more uniform across appellate panels than across the trial bench, a system of appeal reduces disparity in legal error, which may be valuable in its own right.

${ }^{100}$ I find it highly implausible that trial courts generally believe that appellate courts are better at deciding issues of law-that, on average, appellate courts will "correct" trial rulings. For the sake of argument only, I ignore this objection.

${ }^{101}$ This hypothesized distribution is the same as the outer curve of Figure A-3 (the distribution of disputes in the trial court) in the Appendix.
} 
Figure I:

Distribution of Confessions in the Trial Court

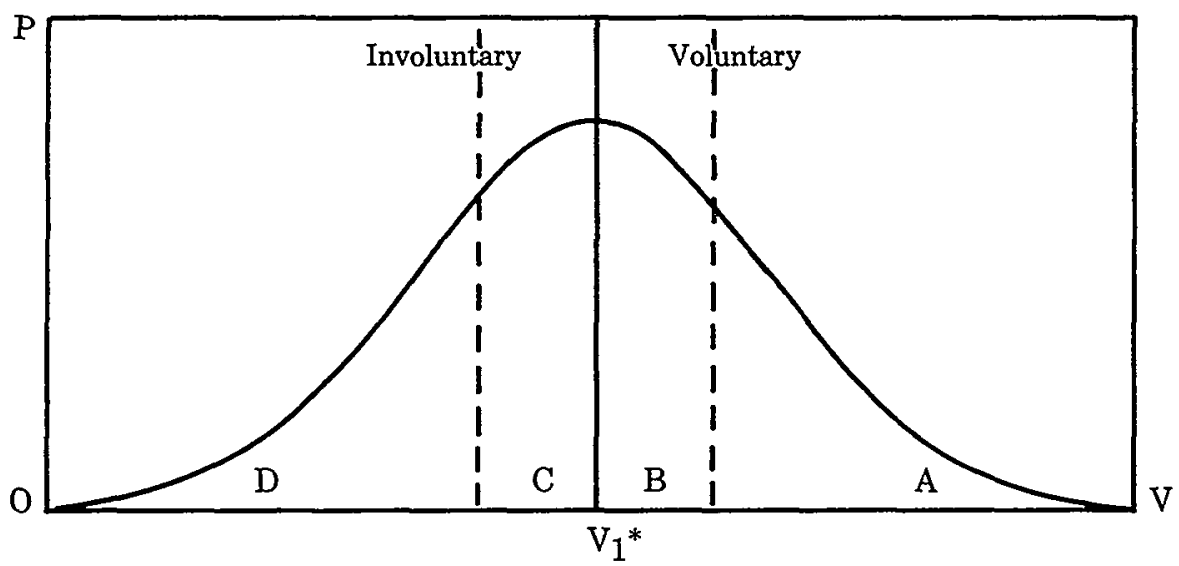

The competing objectives of avoiding reversal and avoiding uncorrected legal error are both strongest when the legal issue is close (Areas B and C of Figure I) and is likely to affect the verdict. ${ }^{102}$ Because these secondary objectives are competing, they may merely cancel each other out, so that, even for disputes that are close and critical, the trial court will seek only to apply the authoritative legal standard. There are at least two reasons, however, to suppose that the two secondary objectives are not entirely commensurate and thus not entirely offsetting. Each consideration suggests that the tendency to avoid reversal will dominate. ${ }^{103}$ First,

${ }^{102}$ In the areas marked $A$ and $D$ of Figure I, where the confession is clearly voluntary or clearly involuntary (relative to the precedential standard), the trial court will simply seek to apply that standard, as explained previously in the text. In Area B, most of the confessions will appear to be voluntary. Yet if the trial court admits the confession, and the result is conviction, the appellate court may reverse on appeal. Hence, the trial court may be tempted to rule for the defendant in order to avoid reversal. Yet ruling for the defendant (suppressing the confession) would increase the risk of uncorrected error in a final judgment of acquittal. In Area $\mathrm{C}$, on the other hand, most of the confessions will appear to be involuntary. Yet if the trial court suppresses the confession and the result is acquittal, there will be no appellate review of the correctness of the trial court's ruling. For this set of cases, then, the trial court may be tempted to rule for the government (admitting the confession) in order to avoid error in a final judgment of acquittal. Yet ruling for the government would increase the risk of reversal.

${ }^{103}$ If, as suggested in note 100 , trial courts do not believe that appellate courts err less often than trial courts, then the incentive for pro-defendant error would predominate in all cases. 
preserving close rulings for review (by ruling for the government even though the defendant's position appears to have more merit) entails significant costs. The parties and the appellate court will bear litigation costs on appeal, while the parties and the trial court itself will bear them on retrial. ${ }^{104}$ Consideration of these costs on the criminal litigation process will weigh against purposely erring for the government.

Second, apart from transactions costs, the two secondary objects respond to incommensurate harms. On close issues of law, any error by the trial court is a "small" error (i.e., the trial court admits a confession in Area $\mathrm{C}$ or suppresses a confession in Area B). But the harm resulting from the legal error is not necessarily small. We have seen that the reason a trial court might tend to rule for the government in close cases is to avoid uncorrected legal error leading to a final judgment of acquittal. Hence, the harm from a pro-defendant legal error is the magnitude of injustice if acquittal results. But it would seem that precisely because the legal issue is close (in Areas B or C), the magnitude of injustice in any resulting acquittal cannot be great. From the trial court's perspective, these confessions are at best barely voluntary; the government at best almost violated the defendant's rights. Hence, where the trial court's possible pro-defendant error is small (because the issue of law is close), the potential harm (injustice) ${ }^{105}$ is small as well.

The harm from a pro-government legal error, on the other hand, is not correlated with the magnitude of the legal error. If the trial court errs in admitting a confession, the potential harm is reversal, which does not come in differing magnitudes. The harm from reversal may well be the same whether the error of law was "small" or "large." "For for disputes that it perceives to be in Area C

204 The trial court bears no similar transaction costs if it errs for the defendant. Where pro-defendant error results in acquittal, however, the government bears the burden of sunk investigation and prosecution costs.

${ }^{103}$ I mean a concept of justice that is formed exclusively by legal standards. If standards of law are the measure of justice, then making a "small" legal error (ruling against the government on a set of facts that barely meets the legal standard) is unjust, but not as unjust as making a "large" legal error (ruling against the government on a set of facts that overwhelmingly exceeds the standard).

If a judge's concept of justice is formed in part by measures independent of legal standards, then a "small" legal error might lead to great injustice. For instance, a judge might think that it is "just" to introduce a confession that is reliable, whether or not it is also voluntary. Such a judge might perceive even a small pro-defendant legal error on the voluntariness issue to be a great injustice, because it prevents admission of a reliable confession. Of course, such a judge would also perceive injustice even when he makes no legal error (i.e., when he suppresses a reliable but constitutionally involuntary confession).

${ }^{108}$ Conceivably, the trial judge who suffers reversal may be comforted by the knowledge 
(barely involuntary), it is unlikely that a court would nonetheless favor the government. A trial court would have a strange conception of justice and of its role if it purposely erred for the government to avoid an "unjust" acquittal, when the expected consequence of such error is reversal and then retrial at which acquittal is more likely. ${ }^{107}$ On the other hand, for disputes that it perceives to be in Area B (barely voluntary), a court might well decide to err for the defendant, which avoids all harm of reversal by increasing the potential of a small injustice. The incentive for pro-defendant error increases as the dispute in Area B approaches the constitutional standard.

The foregoing suggests that Professor Damaska's insightthat trial courts might consciously err in favor of the government in order to avoid legal error in final judgments - is not generally plausible. The incentive for pro-defendant error-avoiding reversal-would seem to outweigh any incentive for pro-government error on close legal issues, particularly where reversal of the pro-government ruling would require retrial. For disputes that are not close, on the other hand, neither incentive is likely to cause the trial court deliberately to err.

The insight is nonetheless critical in one set of cases: those where the law is highly uncertain or the issue is novel. In Figure I, the trial court cannot easily place these cases either far from the standard (Areas A and D) or close to the standard (Areas B and C), because it simply does not know what the standard is. If the trial court rules for the defendant (proceeding as if the dispute were in Area $\mathrm{C}$ or $\mathrm{D}$ ), it will avoid reversal, but the result could be significant injustice (where the dispute in fact falls within Area A). On the other hand, if the trial court rules for the government, its decision may be reversed, but appellate review and possible retrial will prevent significant injustice in the final judgment. Hence, for novel or difficult-to-categorize legal issues, the asymmetry in criminal appeal rights may indeed lead the trial court to err for the government, not to minimize error under a prevailing appellate standard, but to obtain authoritative delineation of the standard.

that his legal error was "small" (i.e., the confession was barely in Area C). If the harm from reversal is to the judge's reputation, then explicit appellate recognition of the "small" nature of the judge's legal error might ameliorate this harm, assuming that reputational sources read the whole appellate opinion. See also note 121 and accompanying text.

${ }^{107}$ See also note 79 (likelihood of conviction is usually reduced on retrial). 


\section{The Consequences of "Harmless Error"}

Previous sections have alluded to the concept of "harmless error": legal error by the trial court that does not affect the verdict. ${ }^{108}$ This concept is critical in appellate review. Where the harmless error rule applies, the appellate court will affirm a trial court judgment that contains legal error if the appellate court deems the error to have been "harmless." The harmless error rule might seem to alter significantly the preceding analysis of pro-defendant bias in legal error. ${ }^{109}$ This section explains why the rule does not in fact undermine the analysis. The harmless error rule increases the total amount of pro-government legal error uncorrected on appeal but does not greatly increase the number of false positives and is not likely to introduce a pro-government bias in the evolution or application of legal standards by trial and appellate courts. Indeed, the rule may permit evolution of more pro-defendant legal standards.

\section{A. The Meaning of Harmless Error}

Prior to the twentieth century, almost all errors identified on appeal from civil or criminal cases required new trials, even when the error only insignificantly prejudiced the affected party. Since the beginning of the century, all fifty states and the federal system have adopted the harmless error doctrine by statute or rule; ${ }^{110}$ the Supreme Court has held that the doctrine can apply to constitutional as well as other errors. ${ }^{111}$

${ }^{108}$ See notes $8,51,80$, and 91 .

100 The short answer to this observation is the Supreme Court's holding that the harmless error rule does not apply to the particular example I have used to illustrate the analysis: involuntary confessions. Payne v Arkansas, 356 US 560, 567-69 (1958). The harmless error rule cannot be ignored, however, because it does apply to most detected legal error on appeal.

110 See, for example, FRCrP 52(a).

111 Chapman v California, 386 US 18, 21-22 (1967). There is a small class of constitutional errors to which the doctrine does not apply. These errors require reversal in the absence of any showing of prejudice to the defendant; for most of these, an irrebuttable presumption of prejudice exists. See, for example, Rose v Clark, 478 US 570 (1986) (racial discrimination in selection of grand jury foreman); Gideon $v$ Wainwright, 372 US 335 (1963) (denial of right to counsel); Payne v Arkansas, 356 US 560 (1958) (coerced or involuntary confession). See also Vasquez v Hillery, 474 US 254, 260-64 (1986) (racial discrimination in selection of grand jury compels dismissal of indictment); Gray v Mississippi, 481 US 648 (1987) (harmless error rule does not apply to unconstitutional exclusion of juror); and United States v Strunk, 412 US 434 (1973) (denial of constitutional right to speedy trial held not subject to harmless error rule even when no prejudice results). In addition, there are other constitutional errors, mostly derived from the Due Process Clause, for which proof of prejudice is an element of the violation itself. Such errors presumably can never be 
The harmless error doctrine requires an appellate court to consider the effect of an identified error on the judgment of the trial court, usually the jury verdict in a criminal trial. For criminal cases, there has been much controversy over the proper standard to apply in determining whether the error's impact on the judgment was so slight as to be "harmless." Stated in terms of probability analysis, an error is harmless if there is a likelihood of at least " $z$ " that the defendant would have been convicted on the other evidence in the case, ${ }^{112}$ with the number assigned to " $z$ " being the major point of contention.

For our purposes, precise specification of the standard is not necessary; it is enough to know that, as actually applied by appellate courts, the doctrine is quite powerful. That is, the harmless error rule causes the appellate court to affirm a substantial number of convictions despite pro-government error below. ${ }^{113}$ Most legal errors, constitutional and non-constitutional, do not automatically result in reversal and retrial. Whether the appellate court reverses depends on the strength of the government's remaining evidence in the case; that is, the probability of conviction absent the error. ${ }^{114}$

\section{B. The Risk of Error with a Harmless Error Rule}

The simple risk analysis presented in Section I did not admit the possibility of harmless error because it assumed a perfect correlation between prevailing on the issue of law and prevailing at

\footnotetext{
"harmless." Compare the majority and dissenting opinions in Strickland $v$ Washington, 466 US 668 (1984); and the majority and concurring opinions in Delaware v Van Arsdall, 475 US 673 (1986).

122 An alternative way to state the harmless error inquiry in terms of probability analysis is that the appellate court must consider the extent to which the error increased the probability of conviction. For purposes of this article, it does not matter how the probability issue is stated. I have formulated the harmless error rule in the way that most courts actually apply it. By and large, courts only consider the strength of the remaining evidence of guilt. This approach is consistent with a Bayesian approach to harmless error. See Daniel J. Kornstein, A Bayesian Model of Harmless Error, 5 J Legal Stud 121, 127 (1976).

113 The author's review of Second Circuit criminal law rulings over a four-month period in 1987 (127 issues discussed in a total of 54 cases) revealed that the appellate court found trial court error in 12 percent of the issues; yet the court also found over 60 percent of these errors to be "harmless." See also notes 52 and 124.

114 The question whether to reverse because of a pro-government legal error (i.e., whether the error is harmful) is different from the question whether the evidence in a case is constitutionally sufficient for conviction. The constitutional sufficiency standard is whether a "reasonable" jury could have convicted. Jackson v Virginia, 443 US 307, 319 (1979). This standard clearly establishes a lower threshold of proof than the harmless error test. If an error is not harmless, the defendant stands trial again. If the evidence was constitutionally insufficient, on the other hand, the case must be dismissed. See note 79 .
} 
the trial itself. ${ }^{116}$ This assumption implied that trial court pro-government error-admitting constitutionally involuntary confessions-could not be harmless. Given this assumption, the earlier analysis further assumed that the appeals court would reverse in all cases infected by pro-government error. ${ }^{116}$

Introducing the possibility of harmless error requires some adjustment of the previous analysis. In the analysis presented in Section I, the defendant bears the risk of pro-government error in the trial court only when the appellate court fails to detect such error. With a harmless error rule, the defendant bears the risk of progovernment error even in some cases where the appellate court detects the error-specifically, in those cases where the likelihood of conviction absent the error exceeded "z." Hence, if the appellate court applies a harmless error rule, the defendant bears the risk of pro-government error in more cases.

Not all of these additional affirmances are false positives, however. They are false positives only when the appellate court wrongly determines that an error was harmless, i.e., when the defendant would have been acquitted in the absence of the legal error. As previously noted, reversals for pro-government legal error result in new trials, some of which will end in conviction even though the pro-government error that tainted the first trial has been eliminated.117 The total number of additional false positives resulting from the harmless error doctrine depends, first, on the probability standard of harmless error-that is, how high " $\mathrm{z}$ " is-and, second, on how accurately the appellate court applies this probability standard. If " $\mathrm{z}$ " is close to 100 percent, the appellate court will not deem an error harmless unless it estimates that the likelihood of conviction on the remaining evidence is close to 100 percent. Under this strict harmless error standard, many convictions will be reversed on appeal for legal error at the first trial, but most of these defendants will also be convicted at a second trial. ${ }^{118}$ As "z" decreases the defendant bears a greater risk of false positives: the appellate court affirms more convictions (some of which were false positives), and a larger proportion of reversals result in acquittal at the second trial.

\footnotetext{
115 See text at note 37 (assumption 3).

116 See note 42 and accompanying text (assumption 8 ).

${ }^{117}$ See note 79 and accompanying text.

118 However, the probability of conviction at the second trial may be less than it would have been at the first trial absent the error. See note 79 .
} 
The harmless error doctrine is a rule of judicial economy; it curtails new trials that are likely to end in the same result as the first trial. In both the civil and criminal contexts, the rule inevitably means that appellate courts will affirm some cases that in fact would end differently on retrial absent the original error. In the criminal context, the doctrine benefits only the government because only pro-government verdicts can be appealed to begin with. Still, the rule does not equalize the overall risk of legal error in criminal cases; while it increases the extent to which the defendant bears the risk of pro-government trial court error, it must be remembered that the government, because it cannot appeal, necessarily bears all risk of pro-defendant error in the trial court.

C. Harmless Error and the Legal Standard Applied in the Trial Court

The foregoing section confirms the common-sense understanding that the harmless error doctrine somewhat increases the risk of pro-government legal error in final judgments of conviction. We now consider whether the doctrine also introduces a pro-government distortion in the actual standard of law applied by trial courts.

1. Assuming that trial courts seek only to apply the authoritative legal standard.

If trial court judges seek only to apply the precedential legal standard, the harmless error rule will not cause the trial court to apply a more pro-government standard than it otherwise would. The harmless error rule does not affect the trial court's perception of that standard.

Even with a harmless error rule, the appellate court must first determine and state whether the prevailing legal standard was satisfied in the case. The harmless error rule means only that, on some occasions, the court will affirm the conviction even though it finds that the standard was not satisfied. Since the trial court infers the standard from appellate rulings (not judgments of affirmance or reversal), it will continue to apply the same standard even with a harmless error rule.

2. Assuming that trial courts also seek to avoid error in final judgments and to avoid reversal. 
If we recognize secondary trial court objectives of avoiding error in final judgments and avoiding reversal, ${ }^{118}$ the analysis becomes more complex, but the conclusion is not materially different. Where the trial court has these secondary objectives, it faces the conflict described in Section IV: favoring the government would preserve its ruling for appeal if the trial ends in conviction, while favoring the defendant would prevent reversal no matter how the case ends. Section IV concluded that the desire to avoid reversal will predominate.

The harmless error rule does not greatly change this analysis because these secondary objectives are most relevant precisely where errors are unlikely to be harmless (i.e., where the rule does not come into play). Any trial court incentive to favor the government, in order to avoid error in a final judgment of acquittal, is greatest where the trial court thinks that an inadvertent pro-defendant error would turn a conviction into an (unappealable) acquittal. But where a pro-government ruling prevents an acquittal, the harmless error doctrine will not be applied on appeal. Analogously, the trial court's incentive to favor the defendant, and thereby avoid reversal, is greatest where the trial court thinks that an inadvertent pro-government error would turn an acquittal into a conviction. Since an appellate court would not deem such an error to be harmless, the harmless error rule does not remove the incentive to favor the defendant in these cases.

Where, however, the trial court is uncertain whether an error would be deemed harmless-as may often be the case ${ }^{\mathbf{1 2 0}}$-the harmless error rule may affect the court's resolution of the legal issue. We have seen that, to the extent the trial court is concerned with avoiding reversal, it has an incentive to rule in favor of the defendant on close issues. The harmless error rule decreases this incentive for conscious pro-defendant error because it accords some protection against reversal should the trial court make an inadvertent pro-government error. The trial court has less incentive to shade its rulings in a pro-defendant direction because the harmless error doctrine already reduces the risk of reversal.

But if the objective of "avoiding reversal" is shorthand for a set of values involving the trial court's reputation and self-esteem, the harmless error doctrine will not ameliorate pro-defendant bias. Where the trial court's concern is with appellate pronouncement of

110 See Section IV.

120 At the time the trial court makes many evidentiary and other rulings, it has not yet seen all of the evidence of guilt and cannot predict the likely outcome of the case. 
trial court error, not simply appellate reversal, ${ }^{121}$ the harmless error doctrine will not affect its incentive to favor the defendant on close issues of law.

Even if the harmless error rule only slightly reduces the incentive to avoid reversal, its impact is not uniform across legal issues or, for any given legal issue, across cases. For many legal standards, the doctrine has no systematic effect on trial court decisions; violation of the legal standard would be "harmless" in cases where other evidence of guilt is strong, but might mean the difference between conviction and acquittal in other cases. The rule probably has its greatest systematic impact on two kinds of legal issues: those that seldom affect trial outcome, and those that are costly to decide correctly. When applying legal prohibitions or prescriptions that do not directly relate to trial outcome, including many grand jury and other pre-trial requirements not subject to immediate appeal, the trial court has little fear of reversal because any error likely will be deemed harmless. Hence we should seldom observe trial courts unduly favoring defendants on these issues. For legal standards that are difficult or costly for the trial court to comply with, the harmless error doctrine may produce particularly undesirable results; where such legal standards implement values unrelated to trial outcome, it may be appropriate not to apply the harmless error doctrine, because fear of reversal may be the major incentive the trial court has to comply with such standards.

\section{Harmless Error and the Appellate Court}

If we assume that the appellate court seeks only to apply the previously articulated standard of law, then the harmless error doctrine by hypothesis does not affect the standard, as explained in the previous section with respect to the trial court.

Perhaps, however, this is the point at which to recognize a possible source of appellate error not yet addressed: appellate prejudice against defendants, who, after all, have been "found" to be criminals. Particularly where the evidence of guilt at trial was very strong, even apart from any pro-government error, the appellate court may be reluctant to reverse.

If such judicial bias against criminal appellants exists, the harmless error doctrine is a near-perfect means of ensuring that

${ }^{121}$ See Van Arsdall, 475 US at 686 (White concurring) ("No judge welcomes or can ignore being told that he committed a constitutional violation, even if the conviction is saved by a harmless-error finding."). 
such bias does not affect the development of legal standards. Without the doctrine, an "anti-defendant" appellate court might conclude that the relevant legal standard had been violated, yet hold (in order to prevent reversal) that the trial court did not make a pro-government error. These additional affirmances (pro-government errors) by the appellate court would cause the legal standard, which is derived from appellate precedent, to shift in a pro-government direction.

The harmless error doctrine effectively insulates the legal standard from this form of judicial bias when there is powerful evidence of guilt apart from the error-precisely the circumstance in which such bias will be strongest. The appellate court can hold that the legal standard was violated, but that the trial court's error was harmless. Commentators have argued that legal standards governing investigation and prosecution in England are more pro-government than in the United States in part because England's harmless error doctrine is relatively narrow: errors are rarely deemed harmless in criminal cases. ${ }^{\mathbf{1 2 2}}$ English appellate courts, reluctant to reverse convictions of the clearly guilty, narrowly interpret defendants' rights and broadly interpret prosecutorial powers. ${ }^{123}$ The harmless error doctrine may prevent this antidefendant bias in the development of criminal law standards in this country. Equally important, if appellate courts are otherwise disposed to expand the scope of defendants' rights in criminal cases, the harmless error rule allows them to do so without necessarily reversing convictions on appeal. ${ }^{124}$

122 The standard in England for harmless error is whether the defendant would have been convicted "without doubt" in the absence of the error. See J. R. Spencer, Criminal Law and Criminal Appeals-The Tail that Wags the Dog, 1982 Crim L Rev 260, 265. This standard is an interpretation of the Criminal Appeal Act of 1968, § 2(1), 39 Stat in Force, ch 19 (1978), which allows courts to affirm convictions in spite of legal error if "they consider that no miscarriage of justice has actually occurred." Spencer asserts that the narrow interpretation of this provision allows courts to "quash the conviction of any appellant who [can] point to any failure of due process." 1982 Crim $L$ Rev at 264. See also Rosemary Pattenden, The Judge, Discretion, and the Criminal Trial 30-31 (Clarendon, 1982).

${ }^{123}$ Spencer suggests that courts narrowly construe due process standards because of the narrow scope of the harmless error doctrine. Spencer, 1982 Crim L Rev at 282. In addition, it should be noted that reversal in England usually leads to outright acquittal, not retrial. Criminal Appeal Act of $1968 \$ \$ 2(2), 2(3)$. See generally Michael Knight, Criminal Appeals (Stevens \& Sons, 1970).

${ }^{124}$ There is some empirical support for the proposition that in criminal appeals the harmless error doctrine produces standards that are more pro-defendant than they would otherwise be. As previously noted, the author's review of a sample of criminal appeals found that over 60 percent of the errors identified by the appellate court were held harmless. See note 113. The author's review of civil appeals for the same period in the same court (201 issues in 104 cases) revealed that only 8 percent of identified trial court errors were held 


\section{CoNCLUSION}

I have analyzed some consequences of the asymmetric structure of appeal in criminal cases. Assuming that courts are otherwise free from party bias, the skewed distribution of cases on appeal not only results in more pro-defendant than pro-government legal error, but may also introduce a pro-defendant bias in the evolution of legal standards and provide an incentive for trial courts to rule in favor of defendants on close legal issues.

The risk analysis developed in Section I (and the more formal model presented in the Appendix) shows how the rule prohibiting government appeals, coupled with near universal appeal by con- victed defendants, produces an asymmetry in the distribution of disputed legal issues on appeal. Assuming that both trial and appellate courts seek to apply the legal standard implied by appellate precedent, there is more pro-defendant legal error than pro-government legal error in final outcomes. ${ }^{125}$

Asymmetry in the distribution of disputes on appeal and in the distribution of appellate legal error is not the result of judicial bias. Nonetheless, these asymmetries may introduce bias in judicial decision making, as suggested in Section II. Even if courts seek only to apply the precedential standard, constraints on their decision processes may cause their perception of that standard to be skewed the same way that the distribution of appellate error is skewed-in a pro-defendant direction. In particular, if the trial court derives the precedential standard by balancing pro-defendant and pro-government appellate inconsistency, it will perceive the appellate court to be applying a more pro-defendant standard

harmless. This suggests that the appellate court used the harmless error doctrine to expand the scope of defendants' rights; the court held that the trial court should have given wider scope to defendants' rights, but did not want to reverse the convictions.

Neither these data nor similar data, however, can confirm the hypothesis that the harmless error doctrine works to the benefit of criminal defendants as a class. The comparison of harmless error rulings in civil and criminal cases is complicated by the fact that the distribution of appeals in criminal cases is skewed in a pro-government direction because nearly all criminal convictions are appealed. See note 39 . This may result both in a lower percentage of errors identified in criminal appeals, see notes 52 and 113 , and in a higher percentage of identified errors that are deemed harmless.

More generally, data cannot reveal how the appellate (or trial) courts would rule in the absence of a harmless error rule for criminal cases. I have suggested that appellate courts would find fewer errors; critics of the harmless error rule apparently assume that the appellate courts would simply reverse more convictions.

125 The analysis in Section I assumes that the distribution of disputes in the trial court is symmetric around the initial legal standard. The relative pro-defendant skew in legal error is even greater under a more plausible distribution of disputes. See text at notes 76-80. 
than the appellate court is actually applying. ${ }^{126}$ The appellate court itself may be misled by or dissatisfied with standards under which the government usually prevails on appeal, and may therefore be disposed to shift legal standards in a pro-defendant direction. ${ }^{127}$

If we relax the assumption that trial courts seek only to apply the precedential legal standard, it becomes evident that the asymmetry in criminal appeals creates additional sources of bias. Section IV considered alternative or supplementary objectives of the trial court: avoiding reversal and (less plausibly) minimizing the risk of uncorrected legal error. The first additional objective militates in favor of more pro-defendant error in the trial court, and the second in favor of more pro-government error, but I conclude that the first effect may be expected to predominate in nearly all cases.

Section V considered the extent to which the harmless error doctrine may counteract pro-defendant biases caused by the prohibition on government appeals. For a limited set of issues, the doctrine may cause trial courts systematically to apply more pro-government standards of law than they would otherwise. But the harmless error doctrine will not ameliorate the trial court's incentive to favor defendants (and thereby avoid reversal) in cases where the incentive is most likely to be determinative. I also suggest that, contrary to the assumption or expectation of many commentators, the harmless error doctrine may actually encourage appellate courts to develop more pro-defendant standards of law.

Although we can identify countervailing ways in which the prohibition on government appeals might increase total pro-government error or introduce pro-government bias into judicial decision making, these effects appear much weaker than the pro-defendant distortions and biases. The rule against government appeals increases pro-government legal error where appeals courts defer to the legal evaluations of trial courts, ${ }^{128}$ where trial courts seek to reduce the risk of uncorrected error, ${ }^{129}$ and where the harmless error rule applies. ${ }^{130}$ In large measure, however, the latter two contingencies simply lessen the pro-defendant bias in applica-

\footnotetext{
${ }^{128}$ See text at notes 61-65. In addition, pro-defendant legal error will increase if the trial court derives the legal standard from random sampling of appellate precedent. See text at notes $59-60$.

${ }^{127}$ See text at notes 66-70.

${ }^{128}$ See text at notes 71-75.

129 See text at notes $98-107$.

${ }^{130}$ See text at notes $115-18$.
} 
tion of the legal standard that would otherwise result from the trial court's efforts to avoid reversal. ${ }^{131}$ Moreover, even in these situations, the rule against government appeals does not exert a continuing pro-government bias in the evolution of legal standards. ${ }^{132}$

At least as important as the pro-defendant biases that asymmetric appellate rights may exert on the evolution and application of legal standards are the adjustments that courts and litigants may make in response. Section III of the article suggested several possible responses, including strategies to achieve a more symmetric distribution of disputes on appeal. The range of cases considered by the appellate court may be effectively expanded by the appellate court explaining in dicta the limits of particular rulings, or by the government as appellee in other cases bringing pro-defendant trial court rulings to the attention of the appellate court. Moreover, litigants, especially prosecutors, may respond strategically to the possibility of selection effects by raising issues that otherwise would not be pursued, thereby achieving a more symmetric distribution of disputes on appeal and reducing selection effects. If trial and appellate courts are not able to adjust for selection effects or engage in self-correction, the Supreme Court may occasionally intervene to reverse unwarranted evolution of a legal standard.

It is possible that these various strategies in isolation or in combination counteract any distortion in the evolution of criminal law standards that would otherwise result from asymmetry in appellate rights. These strategic responses may not themselves be desirable, however, and, in any event, cannot counteract the incentive that asymmetry in criminal appeals provides for trial judges to favor defendants on close issues of law. ${ }^{133}$

Yet the one-sided incentive for trial court error in criminal cases also is not an inevitable consequence of our criminal justice system. It is possible to reduce the asymmetry in criminal appeal rights without permitting the government to appeal jury acquittals. In the federal system and all state systems, the government has long been permitted to appeal certain pre-trial dismissals of indictments. I have noted that in 1968 Congress authorized the govern-

131 See text at notes 98-103 (regarding trial court objective of reducing risk of erroneous acquittal); and text at notes 120-121 (regarding application of the harmless error doctrine).

${ }_{132}$ A secret policy of appellate deference could result in a pro-government shift in the standard, but if the trial court (or other observers) are aware of the policy, the standard of law derived from precedent will not shift. See text at notes 89-91.

${ }^{133}$ See notes $92-97$ and accompanying text. 
ment to appeal pre-trial rulings suppressing evidence. ${ }^{134} \mathrm{~A}$ major impetus for the 1968 legislation was the Report of the President's Commission on Law Enforcement and Administration of Justice, The Challenge of Crime in a Free Society. ${ }^{135}$ The Commission rejected the argument that the absence of government appeals makes no difference in the development and application of legal standards. As the Commission explained:

When the prosecution is not permitted an appeal, law enforcement officials faced with restrictive rulings they feel are erroneous have available two courses, each of which is undesirable: They can follow the lower court decision and abandon the practice, in which case an authoritative decision by an appellate court may never be obtained, or they can continue the practice, hoping that in a future case a trial court will sustain it and that a defendant by appealing will give the higher court an opportunity to resolve the point. ${ }^{136}$

In other words, when the government is not allowed to appeal, erroneous pro-defendant rulings in the trial court may never be corrected. The appellate court may continue to apply the correct standard, but, absent a maverick prosecutor and trial court, the trial court will continue to apply the wrong standard.

The present analysis suggests that the potential distortions in the law resulting from one-sided appeal are even more significant than the 1968 Report indicated. Asymmetric appellate rights mean not only that erroneous pro-defendant law in the trial court may never be corrected, but also that the legal standards enunciated by appellate courts or applied by trial courts may shift in a pro-defendant direction. ${ }^{137}$ Moreover, to the extent that courts and liti-

\footnotetext{
134 See note 44 and accompanying text. This portion of 18 USC $\S 3731$ (1982 \& Supp 1989) provides:

An appeal by the United States shall lie to a court of appeals from a decision or order of a district courts [sic] suppressing or excluding evidence . . . not made after the defendant has been put in jeopardy ... if the United States Attorney certifies to the district court that the appeal is not taken for purpose of delay and that the evidence is a substantial proof of a fact material in the proceeding.

In previous years, similar legislative initiatives had been unsuccessful. See, for example, Improving Federal Law Enforcement and Administration of Justice, S Rep No 85-1478, 85th Cong, 1st Sess (as extended) 14-17 (1958).

135 President's Commission on Law Enforcement and Administration of Justice, The Challenge of Crime in a Free Society 140 (GPO, 1967).

136 Id.

137 The Commission's argument about trial court error applies also to appellate lawmaking. The appellate court has less opportunity to revise a pro-defendant change in the law that it made previously than it has to revise a pro-government change in the law. See
} 
gants are aware of the possibility of pro-defendant bias in the evolution and application of legal standards, they may be expected to adjust their behavior. In particular, in order to counteract distortion in the evolution of criminal standards, prosecutors may assert claims of dubious legal merit that they would otherwise forego.

Congress has more recently authorized additional government appeal from pre-trial rulings and from other adverse rulings that do not implicate the Constitution's Double Jeopardy Clause. ${ }^{138}$ Nonetheless, under the present structure of criminal trials, the government may not appeal many issues of law, especially those relating to the conduct of a trial, to admission of evidence, and to jury instructions. ${ }^{139}$ For these legal issues, asymmetry in appellate rights and in legal error may distort the application and evolution of legal standards-not because such distortion is constitutionally desirable and not because courts are biased on average, but because of the peculiar consequences of asymmetric appeal rights on the judicial decision making process.

If we restructured criminal litigation to encourage greater pretrial consideration of legal disputes likely to arise at trial, ${ }^{140}$ we

note 83 and accompanying text.

${ }_{138}$ See Act of January 2, 1971, Pub L No 91-644, 84 Stat 1890 (1971), codified at 18 USC § 3731 (1982 \& Supp 1989); Act of October 12, 1984, Pub L No 98-473, 98 Stat 1986, 2153 (1984), codified at 18 USC $\S 3731$ (1982 \& Supp 1989). Together, these statutes authorize the government to appeal any trial court order "dismissing an indictment or information or granting a new trial after verdict or judgment ... except that no appeal shall lie where the double jeopardy clause of the United States Constitution prohibits further prosecution." In some state systems and in the federal system (the latter under the Sentencing Reform Act of 1984, Pub L No 98-473, 98 Stat 1988 (1984), codified at 18 USC § 3551 et seq and 28 USC $\$ 991-98$ (1982 \& Supp 1989)), the government may appeal criminal sentences. The constitutionality of such review was upheld against a double jeopardy attack in United States v DiFrancesco, 449 US 117, 133-38 (1980).

${ }^{138}$ Present federal law does not authorize government appeals in all instances not prohibited by the Double Jeopardy Clause. Only some adverse pre-trial evidentiary rulings are appealable-those suppressing evidence. Hence, the government may not appeal pre-trial rulings that grant a defendant's motion in limine to present certain evidence, that relate to the conduct of trial, or that formulate jury instructions. Furthermore, the trial court apparently has discretion to defer ruling on some pre-trial motions until after jeopardy has attached, thereby preventing government appeal. See, for example, United States v Valencia, 826 F2d 169 (2d Cir 1987); and United States v Barletta, 644 F2d 50 (1st Cir 1981). See also United States v Tom, 787 F2d 65 (2d Cir 1986) (government cannot appeal pre-trial dismissal of portion of count in indictment where dismissed portion is not "discrete basis of liability"); contra, United States v King, 827 F2d 864 (1st Cir 1987).

${ }_{100}$ Some trial courts, largely on their own initjative, undertake wide-ranging pre-trial disposition of legal issues in complex criminal cases, as is routine in complex civil cases. See the pre-trial rulings of Judge Gesell in United States $v$ North (for example, 708 F Supp 364 (D DC 1988); 708 F Supp 370 (D DC 1988); and 708 F Supp 372 (D DC 1988)). But see also Cipollone v Liggett Group, Inc., 1990 WL 184, $49-50$ (3d Cir, Jan 5, 1990) (Gibbons concurring) (arguing, inter alia, that previous interlocutory appeal, on theory of liability, should 
could instill greater symmetry in appellate rights. ${ }^{141}$ Before undertaking any wholesale restructuring of criminal procedure, ${ }^{142}$ however, we need further empirical research on the extent of pro-defendant-or pro-government-bias resulting from the present asymmetry in criminal appeal rights. This research may be difficult. Selection effects exist only if courts and prosecutors are unaware of them or otherwise unable to adjust for them. ${ }^{143}$ I doubt that readily available data exist that would document the presence or absence of selection effects in various circumstances. Nor can data on reversals and affirmances, or on application of the harmless error rule, reveal the extent to which trial courts have an incentive to commit pro-defendant error to avoid reversal. ${ }^{144}$ Carefully constructed interviews with judges may be the most promising avenue of research to determine the extent of selection effects and of incentives for trial court error. Until this research is conducted and firmer conclusions can be drawn, judicial awareness of the possibility of inadvertent biases and pernicious incentives may be the best antidote to these unintended effects.

not have been taken in absence of a factual record).

${ }^{141}$ It has also been proposed that where pre-trial consideration of an evidentiary issue is not appropriate, a significant mid-trial ruling against the government should under certain circumstances be cause for a mistrial on grounds of "manifest necessity," see note 38, thereby permitting government appeal and retrial without violation of the Double Jeopardy Clause. See Note, Reviewing the Unreviewable Judge: Federal Prosecution Appeals of MidTrial Evidentiary Rulings, 99 Yale L J 905 (1990). This approach to increasing symmetry in criminal trial appeals clearly would involve a radical (and disruptive) restructuring of criminal litigation.

142 There are two statutory changes that could enlarge opportunities for government appeals in criminal cases without clearly running afoul of the prohibition on double jeopardy. First, Congress might authorize the government to appeal bench trial acquittals, as opposed to jury acquittals, when correction of the judge's legal error would allow a guilty verdict to be entered without a new trial. Second, Congress might authorize government appeals regarding jury instructions where the jury's special findings of fact are inconsistent with its general verdict of acquittal. These proposals are briefly discussed in a publication of the Office of Legal Policy of the United States Department of Justice, Report to the Attorney General: Double Jeopardy and Government Appeals of Acquittals (GPO, 1987).

${ }^{143}$ See Section III generally.

${ }^{144}$ See note 124. 


\section{Appendix}

\section{Graphic ANalysis of the Risk of Error}

The following graphs are based on two key assumptions underlying the risk analysis in Section I: (1) unbiased legal error in both the trial and appellate court; and (2) a symmetric distribution of confessions in the trial court around the constitutional standard.

Figure A-1:

Probability Density Function for the Trial Court's

Estimate of the Voluntariness Index

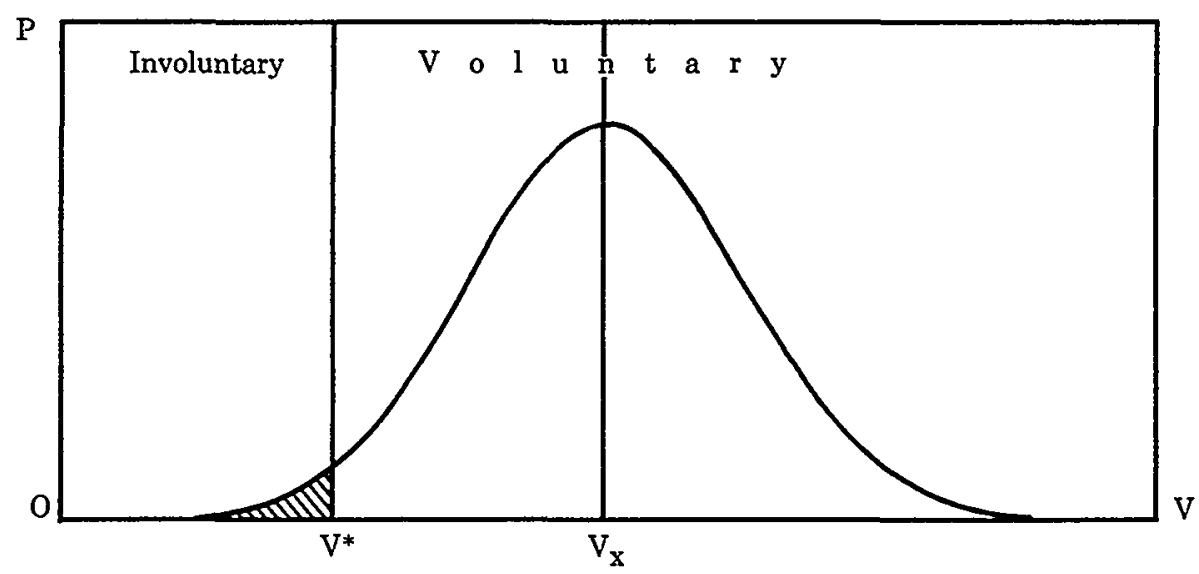

1. Figure A-1 is a schematic representation of a court's assessment of the voluntariness of confessions. The horizontal axis is the voluntariness continuum and measures the index of voluntariness, $\mathrm{V}$ : the further to the right the index value, the more voluntary the statement. The vertical axis measures probability. The curve graphed on these axes shows the probability density function $f(v)$, where $\mathrm{v}$ is the trial court's estimate of the voluntariness index, for a confession with an actual voluntariness index of $V_{x}$. Hence the curve illustrates the distribution of possible voluntariness indices that a court will assign to a confession with an actual voluntariness level of $\mathrm{V}_{\mathrm{x}}$. Note that the curve in Figure A-1 is the density function for a distribution centered at the true index value, $V_{X}$, because of the assumption of unbiased judicial error. Accordingly, over the set of confessions with a true index value of $V_{x}$, the court will implicitly assess a value higher (more voluntary) than $V_{X}$ half 
of the time, and a value lower (less voluntary) than $V_{X}$ half of the time.

Figure A-1 also depicts the constitutional standard, V*. This is the initial precedential legal standard. Because $V_{X}$ is greater than $\mathrm{V}^{*}$, all confessions with this implicit voluntariness index are constitutionally voluntary and should be admitted into evidence. However, the trial court will erroneously suppress a confession with a $V_{X}$ index level in a small proportion of cases (represented by the shaded area in Figure A-1) because the court erroneously perceives the level of voluntariness to be below $V^{*}$. In Figure A-1, for instance, the constitutional standard and the actual level of voluntariness are positioned so that the shaded area is five percent of the area under the curve-meaning that there is a five percent probability that a trial court will erroneously suppress a confession that has a true voluntariness index of $V_{x}$.

Figure A-2:

Probability of Trial Court Error

Conditional on the True Value of the Voluntariness Index

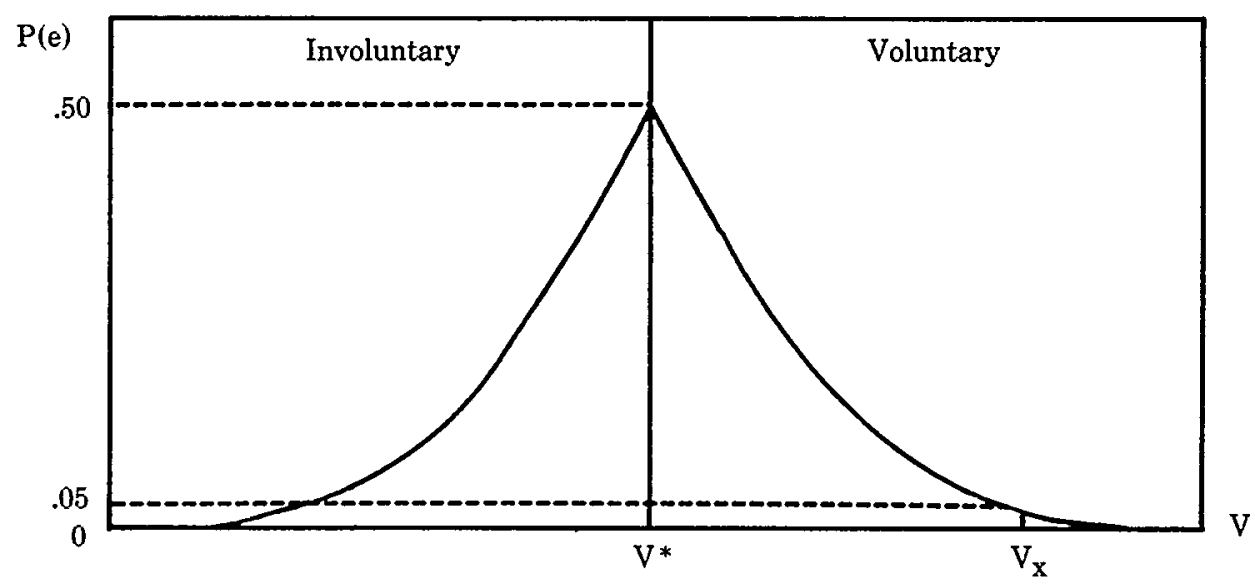

2. For confessions at each level of voluntariness, there is a probability density function like that in Figure A-1. These density functions enable us to derive the court's error characteristic in Figure A-2: the probability of legal error as a function of each true index level, given that the constitutional standard is $\mathrm{V}^{*}$. The horizontal axis is again the actual voluntariness continuum; the vertical axis, however, measures the probability of error. Figure A-2 is 
derived by integrating at each level of voluntariness the corresponding density function (Figure A-1) over the error interval. See Howard Raiffa, Decision Analysis: Introductory Lectures on Choices Under Uncertainty 281-82 (Addison-Wesley, 1970). For instance, when the index equals $V_{x}$, the probability of error equals five percent (on the vertical axis), which is consistent with Figure A-1. More generally, the likelihood of legal error is a decreasing function of the distance between the actual index level and the constitutional standard; error is less likely when the actual index level is much greater or much smaller than the constitutional standard. Where the actual index level equals the standard, there is a fifty percent chance that the court will err.

Figure A-3:

Distribution of Disputes in the Trial Court and Distribution of Trial Court Errors

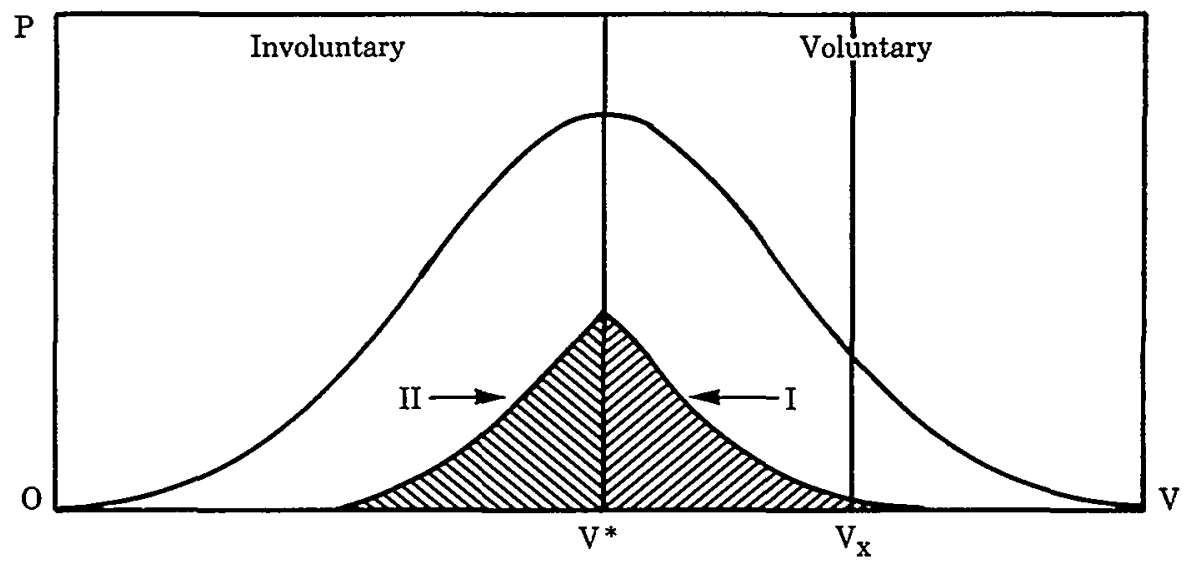

3. The horizontal axis of Figure A-3 again measures the voluntariness index level (V), while the vertical axis measures probability. The outer curve of Figure A-3 shows the distribution of confessions that are disputed in the trial court, with the area under the curve normalized to one. Hence, for each index level, the area under the outer curve of Figure A-3 to the left of the index level gives the percentage of contested confessions with that index or lower. The simple risk analysis in Section I of the text and in this graphical demonstration assumes a distribution of confessions in the trial court that is symmetric around the constitutional standard, $\mathrm{V}^{*}$, with most confessions near the standard.

Multiplying the probability of error for each voluntariness level (from Figure A-2) by the distribution of contested cases (de- 
picted in the outer curve of Figure A-3) yields the distribution of legal error, which is shown as the inner curve of Figure A-3. The shaded area to the right of $\mathrm{V}^{*}$ (noted as area $\mathrm{I}$ ) shows cases in which the trial court makes pro-defendant error-that is, cases in which a confession is erroneously suppressed. The inner shaded area to the left of $\mathrm{V}^{*}$ (noted as area II) shows cases in which the trial court makes pro-government error-that is, cases in which a confession is erroneously admitted. Where the actual voluntariness index approaches the standard, trial court error approaches fifty percent (hence the height of the inner curve is half the height of the outer curve). Because area I and area II are symmetric and equal in size, the incidence of pro-defendant and pro-government error is the same.

Figure A-3 is related to the numerical example provided in note 50 and Table 1 in note 51 . In order to depict legal error more vividly, however, Figure A-3 illustrates a higher overall incidence of legal error than the 10 percent hypothesized in the numerical example. Area I in Figure A-3 corresponds to Box B (pro-defendant errors) and area II corresponds to Box C (pro-government errors).

Figure A-4:

Distribution of Disputes on Appeal and

Distribution of Appellate Error

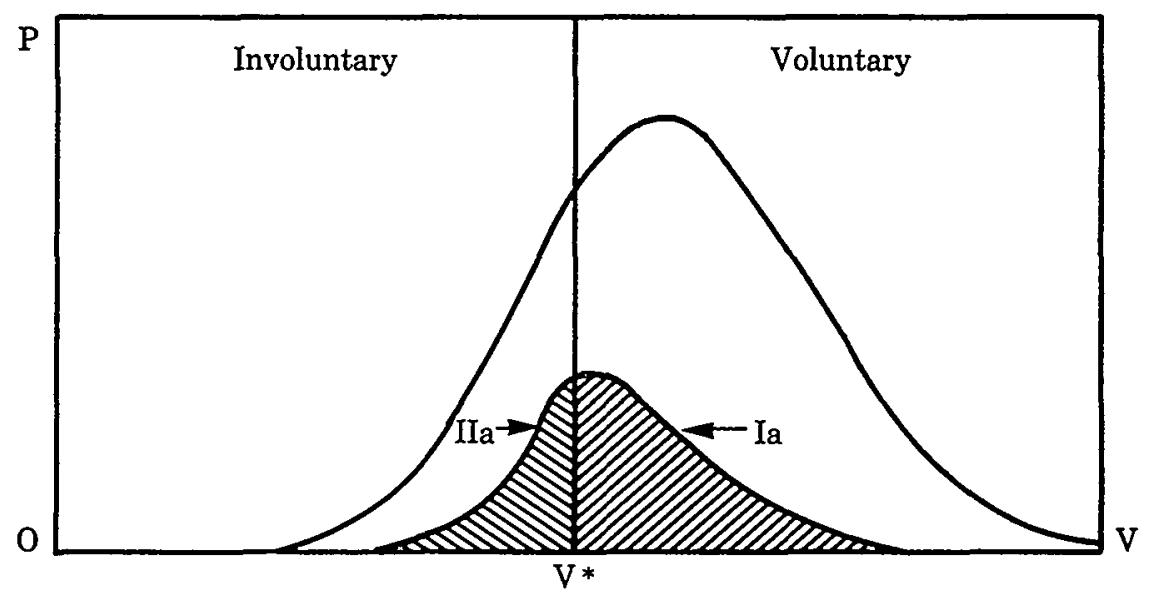

4. The outer curve of Figure A-4 depicts the distribution of cases on appeal raising the voluntariness issue, which is identical to the distribution of confessions admitted by the trial court. Accordingly, the cases under the outer curve in Figure A-4 are those 
that are in area II and in the unshaded area between area I and the outer curve in Figure A-3. Because pro-defendant rulings (suppression rulings) cannot be appealed, the distribution is asymmetric; it is skewed to the right of the constitutional standard, $\mathrm{V}^{*}$.

Multiplying the probability of error for each voluntariness level (from Figure A-2) by the distribution of appealed cases (depicted in the outer curve of Figure A-4) yields the distribution of appellate error, which is the inner curve of Figure A-4. (I have assumed that the trial court and the appellate court have the same error characteristic. This assumption is not necessarily realistic, however. See note 99.) The appellate court should affirm in all cases to the right of $\mathrm{V}^{*}$ because these confessions are voluntary, and it should reverse in the few cases to the left of $\mathrm{V}^{*}$ because these confessions are involuntary. In fact, however, the appellate court occasionally reverses in cases with index levels greater than $\mathrm{V}^{*}$ (area Ia), and occasionally affirms in cases with index levels less than $\mathrm{V}^{*}$ (area IIa). Area Ia consists of pro-defendant appellate error, while area IIa consists of pro-government appellate error.

Figure A-4 is related to the numerical example provided in note 52 and Table 3 in note 54. Total pro-defendant error consists of area $I$ in Figure A-3 (50 trial errors in the numerical example) plus area Ia in Figure A-4 (the 36 appellate errors in the example of note 54), while total pro-government error consists of area IIa in Figure A-4 (the 10 appellate errors in the numerical example).

Figure A-5:

Perceived Standard of Law from Balancing Instead of Minimizing Appellate Error

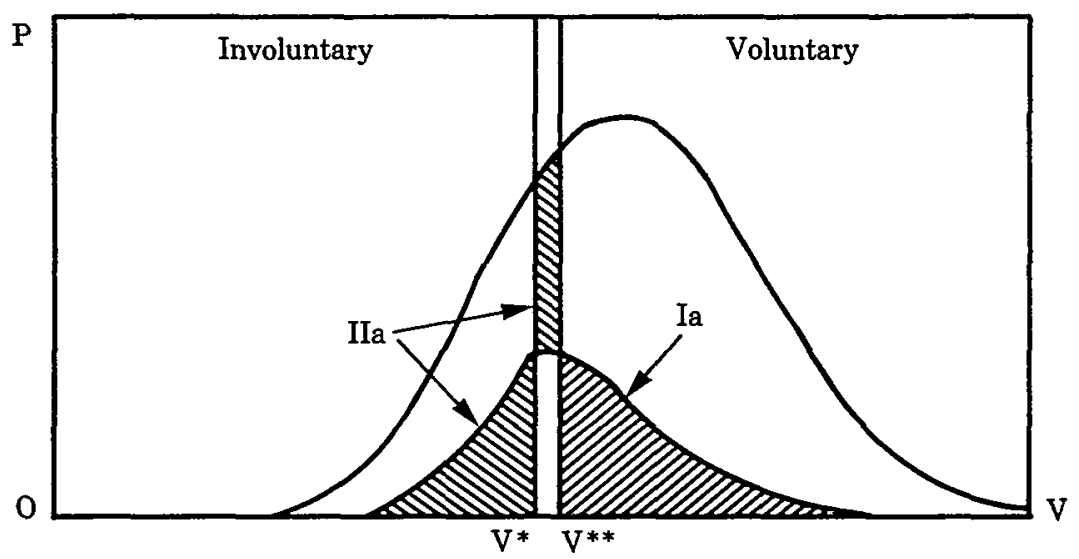

5. Figure A-5 reproduces the appellate outcomes shown in Fig- 
ure $\mathrm{A}-4$, and shows the standard, $\mathrm{V}^{* *}$, at which apparent pro-defendant error (area Ia of Figure A-5) equals apparent pro-government error (area IIa of Figure A-5). This is the standard which the trial court (or other observer) with constrained decision making resources will perceive if it balances instead of minimizes inconsistency in appellate rulings. At the standard $V^{* *}$, a portion of area Ia in Figure A-4-that portion under the inner curve between $V^{*}$ and $\mathrm{V}^{* *}$-becomes unshaded because the appellate rulings in this area appear to be correct under the higher standard of voluntariness. At the same time, the larger area between the two curves for values between $\mathrm{V}^{*}$ and $\mathrm{V}^{* *}$ becomes part of area IIa in Figure A-5 because the appellate rulings in this area appear to be erroneously pro-government under the higher standard. $\mathrm{V}^{* *}$ is a higher (more pro-defendant) standard than is $\mathrm{V}^{*}$. 
